\title{
Fostering Cumulative INNOVATION IN THE BIOPHARMACEUTICAL INDUSTRY: THE ROLE OF PATENTS AND ANTITRUST
}

\author{
By Arti K. Rai
}

\begin{abstract}
This Article addresses the question of how the tools of patent and antitrust law can best be used to foster the cumulative process that is biopharmaceutical innovation. This issue is of particular moment because we have begun in recent years to see a substantial amount of vertical and horizontal integration in the biopharmaceutical industry. The Article argues that although horizontal concentration may be useful for appropriating the value of a lengthy and expensive research and development process, a role for competition needs to be preserved. In the context of the biopharmaceutical industry, broad patents, particularly on upstream invention, represent the main threat to competition. Thus patent law needs to take the lead in preserving competition, primarily by limiting the scope of patents on upstream invention. Antitrust law, and especially the theory of innovation markets, should play a secondary role. In this secondary role, innovation markets theory will actually support certain market transactions that aggregate patent rights, in particular procompetitive patent pools. Innovation markets theory will, however, have an important impact in restricting market transactions if the transactions will give a single entity control over what appears to be a fundamental platform technology.
\end{abstract}

\section{TABle of ConTENTS}

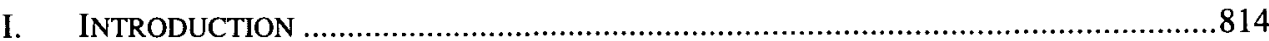

II. CONCENTRATION VERSUS COMPETITION: THE BACKGROUND THEORY..................823

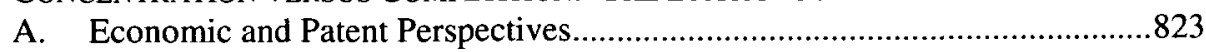

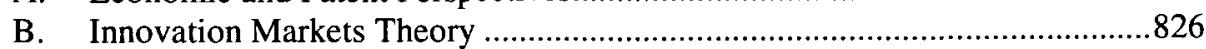

III. Cumulative InNovation IN Biopharmaceuticals: The Role oF

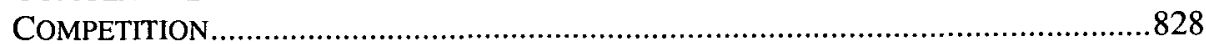

A. Arguments in Favor of Broad Upstream Rights ......................................828

B. Why We (Nonetheless) Need Competition.............................................831

(C) 2001 Arti K. Rai.

$\dagger$ Professor of Law, University of Texas Law School. I thank John Barton, Rebecca Eisenberg, Dan Ellis, Suzanne Scotchmer, and the participants at the "Beyond Microsoft: Antitrust, Technology, and Intellectual Property" Conference at the Boalt Hall School of Law, University of California, Berkeley for helpful comments. 
C. How Patent Law Can Foster Competition .838

IV. OVERCOMING LINGERING IMPEDIMENTS TO COMPETITION: THE ROLE OF ANTITRUST LAW

A. Encouraging Cooperative Interactions Between Horizontal Competitors .....845

B. Restrictive Implications of Innovation Markets Analysis.............................848

C. How Do We Define the Innovation Market? .................................................850

V. CONCLUSION

\section{INTRODUCTION}

The complementary industries of biotechnology and pharmaceuticals (collectively, the "biopharmaceutical" industry) raise a number of vexing issues that lie at the intersection of intellectual property and antitrust. For example, settlements of patent infringement lawsuits between drug manufacturers and their potential generic competitors often raise antitrust concerns. ${ }^{1}$ These settlements, which have been much discussed and are currently being investigated by the Federal Trade Commission ("FTC"), forestall competition in traditional end-product, or goods markets. ${ }^{3}$ Less

1. See, e.g., Sheryl Gay Stolberg \& Jeff Gerth, Keeping Down the Competition; How Companies Stall Generics and Keep Themselves Healthy, N.Y. TIMES, July 23, 2000, at 1; Alfred B. Engelberg, Special Patent Provisions for Pharmaceuticals: Have They Outlived Their Usefulness?, 39 IDEA 389, 416-17 (1999) (critiquing such agreements).

2. See FTC Rx Drug Patent Investigation Moving Forward; Information Requests Expected By Spring, 13 HEALTH NEWS DAILY 3 (2001) (discussing pending investigations and future study).

3. Notably, settlements of patent disputes between brand-name pharmaceutical manufacturers and generic companies are often quite different from patent settlements in other industries. Drug Price Competition and Patent Term Restoration (Hatch-Waxman) Act, Pub. L. No. 98-417, 98 Stat. 1585 (codified as amended in scattered sections of 15 U.S.C., 21 U.S.C., 28 U.S.C., and 35 U.S.C.), which specifically addresses pharmaceutical patenting, has a peculiar structure that allows brand-name manufacturers to forestall all generic competition for a period of time through the simple expedient of settling with the first competitor to challenge the patent. See, e.g., Carl Shapiro, Navigating the Patent Thicket: Cross-Licenses, Patent Pools, and Standard-Setting, in 1 INNOVATION POLICY AND THE ECONOMY (Joshua Lerner \& Scott Stern, eds. forthcoming 2001) (manuscript at 28-29, at http://haas.berkeley.edu/ shapiro/thicket.pdf) (noting that "the branded manufacturer may be able to stall competition by entering into a suitable agreement with the uniquely-placed generic manufacturer, knowing that subsequent rivals will face some delay"). This settlement procedure operates without regard to how marginal the patent being challenged is. Indeed, the structure of Hatch-Waxman strongly encourages brandname pharmaceutical companies to secure marginal drug patents that supplement the main patent application on the chemical entity that is the drug. Even patents that encompass such dubious subject matter as methods of administration, dosage, or tablet shape can be the basis for an automatic 30-month delay in a competitor's ability to market. For a lengthy discussion of the incentives created by Hatch-Waxman, see Arti K. Rai, The 
discussed, but equally important, are antitrust and competition issues raised by patent rights in the cumulative innovation process that leads to an end-product drug. ${ }^{4}$ This Article addresses the question of how patent and antitrust law should be structured in order to promote such innovation.

In order to understand the process of cumulative innovation in the biopharmaceutical industry, it is necessary to appreciate the basic structure of the industry and the science on which it relies. In the 1970s and 1980s, the biotechnology industry functioned relatively independently of the pharmaceutical industry. Biotechnology companies used recombinant DNA technology to produce therapeutic proteins such as insulin or erythropoetin. ${ }^{5}$ Although pharmaceutical companies may have assisted biotechnology

Information Revolution Reaches Pharmaceuticals: Balancing Innovation Incentives, Cost, and Access in the Post-Genomics Era, 2001 ILL. L. REV. (forthcoming 2001).

4. In most industries, cumulative innovation also includes innovation that improves upon (and hence competes with) the first-generation end product. In the biopharmaceutical industry, however, most cumulative innovation occurs in the pre-commercial stage, before the initial marketable product (typically a drug) is produced. Once the marketable drug has been developed, it is generally not the subject of significant improvement by competitors in the end-product market. Rather, to the extent the initial innovator faces competition, it is from so-called "me-too" drugs (that is, drugs that perform the same function as the breakthrough drug but manage to do so without infringing the breakthrough patent) or by generic competitors (once the drug goes off patent). One notable exception to this generalization has arisen in situations where the patented drug is not a traditional small molecule chemical but, rather, a biologic (e.g., a protein or other macromolecule) and the improver has come up with a dramatically different method for producing the biologic. See, e.g., Amgen, Inc. v. Hoechst Marion Roussel, Inc., 126 F. Supp. 2d 69 (D. Mass. 2001); Scripps Clinic \& Research Found. v. Genentech, Inc., 927 F.2d 1565 (Fed. Cir. 1991)). Because this Article focuses on sequential innovation at the precommercial stage, it does not examine antitrust and patent policy issues raised by the possibility of collusive licensing where the second-generation product is a substitute in the end-product market for the first-generation product. Compare Suzanne Scotchmer, Standing on the Shoulders of Giants: Cumulative Research and the Patent Law, $5 \mathrm{~J}$. ECON. PERSP. 29, 33-34 (1991) (giving limited endorsement of such collusion on the theory that it would allow the first innovator to profit from the externality conferred on later innovators) with Howard F. Chang, Patent Scope, Antitrust Policy, and Cumulative Innovation, 26 RAND J. ECON. 34 (1995) (arguing that such collusive licensing should not be permitted). In addition, because this Article focuses on cumulative innovation, it does not address questions of patent breadth that arise when only a single innovator is involved. For articles that address patent breadth in the context of a single innovator, see, for example, Richard Gilbert \& Carl Shapiro, Optimal Patent Length and Breadth, 21 RAND J. ECON. 106 (1990); Paul Klemperer, How Broad Should the Scope of Patent Protection $B e$ ?, 21 RAND J. ECON. 113 (1990).

5. See Rebecca S. Eisenberg, Re-Examining the Role of Patents in Appropriating the Value of DNA Sequences, 49 EMORY L.J. 783, 784 (2000) (noting that biotechnology in the 1980s focused on "cloned genes that enabled the production of proteins through recombinant DNA technology"). 
firms in shepherding these biological macromolecules through the Food and Drug Administration's ("FDA") mandated clinical testing and approval process, the two categories of companies typically did not collaborate at the pre-clinical research stage. For their part, pharmaceutical companies produced small molecule chemical drug therapies based on "wet lab" testing of these therapies against a relatively small library of proteins thought to be involved in various disease processes. ${ }^{6}$

By contrast, in today's world, there is no clear distinction between the research paths taken by biotechnology and pharmaceutical companies. Although pharmaceutical companies still tend to focus on small molecule drugs, ${ }^{7}$ almost all pharmaceutical research is based on genetic or proteomic information. Because this information is often owned by biotechnology companies, pharmaceutical companies now need to work quite closely with biotechnology companies. ${ }^{8}$ Thus, for example, a pharmaceutical company that was interested in developing a drug for Alzheimer's disease would need access to gene fragments or genes relevant to the disease. This "upstream" research (i.e., research that is relatively far removed from a commercial end product) ${ }^{9}$ might be owned by one or more biotechnology firms, thus making it necessary for the pharmaceutical firm to negotiate with the biotechnology firm. Alternatively, a pharmaceutical company that was interested in developing a "precision" drug targeted to individuals with a particular genetic subtype of a given phenotypic disease ${ }^{10}$ would need information on the slight DNA variations, or single nucleotide poly-

6. See From Sequence to Sales, The Genomics Payoff, MED AD NEwS, July 1, 2000, at 29 [hereinafter The Genomics Payoff] (quoting Mark D. Gessler, president of Gene Logic, as saying that drugs developed by the traditional pharmaceutical industry affected fewer than five hundred proteins).

7. Small molecule drugs can be taken orally, as contrasted with macromolecular therapies, which have to be injected.

8. See Josh Lerner \& Robert P. Merges, The Control of Strategic AlliANCES: AN EMPIRICAL ANALYSIS OF BIOTECHNOLOGY COLLABORATIONS 1, tbl. 2 (Nat'l Bureau of Econ. Research, Working Paper No. 6014, 1997) (noting substantial increase in number of collaborations between biotechnology and pharmaceuticals between 1981 and 1995).

9. Throughout this Article, I will use the terms "upstream" and "downstream" to identify the proximity (temporal and conceptual) of particular research to a particular end product. It should be emphasized, however, that these classifications are quite fluid. Thus, for example, research identifying a gene linked to a disease might be quite "upstream" if the commercial goal is a drug therapy. By contrast, if the commercial goal is a diagnostic test, research identifying the gene might be relatively "downstream."

10. Conditions that appear to be the same disease phenotypically (i.e., in clinical presentation) often differ in their genetic basis. Thus drugs that treat one subtype of a particular phenotype may be ineffective in treating another subtype. 
morphisms ("SNPs") that are responsible for, or linked to, the subtype. ${ }^{11}$ Because much of this SNP research has been done by biotechnology companies (e.g., CuraGen), ${ }^{12}$ the pharmaceutical firm would need to negotiate with the biotechnology firm.

In fact, negotiations between biotechnology and pharmaceutical companies have moved well beyond arm's-length licensing. Indeed, research collaborations between the two industries have become widespread and have taken a variety of forms. On occasion, we have seen complete vertical integration, either through a biotechnology company's downstream expansion or through a pharmaceutical company's upstream expansion. Thus, for example, the pharmaceutical company Novartis has established a research laboratory known as the Genomics Institute that has been given a substantial degree of independence in its operations. ${ }^{13}$ Similarly, Pfizer has established a new Global Research and Development Center that conducts basic research in drug discovery using genomics tools. ${ }^{14}$ Conversely, biotechnology companies like Human Genome Sciences, Millennium, and Abgenix have moved downstream into clinical research and development ("R\&D"). ${ }^{15}$

Where pharmaceutical and biotechnology companies have stopped short of complete vertical integration, they have formed strategic alliances, many of which involve a tight linkage between the collaborating partners. For example, biotechnology companies often sign deals with pharmaceutical companies in which collaboration starts very early in the research process. ${ }^{16}$ In some of these alliances, even such early-stage research as the

11. For a discussion of SNP-based "precision" therapies, see Allen D. Roses, Pharmacogenetics and the Practice of Medicine, 405 NATURE 857 (2000). SNP information may also be useful to pharmaceutical companies for the purposes of predicting adverse drug reactions and finding disease genes. See, e.g., Leslie Roberts, SNP Mappers Confront Reality and Find It Daunting, 287 SCI. 1898 (2000).

12. See The Genomics Payoff, supra note 6 (discussing extensive work on SNPs by CuraGen).

13. See Genomics Institute of the Novartis Foundation, About GNF, at http://www.gnf.org/smenu/about.htm (last visited Apr. 22, 2001).

14. Ronald Rosenberg, Discovery Zone Amid a Reshaping of the Drug Industry; Giant Pfizer Inc. Opens Itself to a New Environment, BOSTON GLOBE, Jan. 17, 2001, at D4.

15. See Jennifer Van Brunt, Grand Ambitions, Signals MAG., Feb. 24, 2001, at http://www.signalsmag.com (discussing how investor financing enabled these companies to raise money and move into product development).

16. See LERNER \& MERGES, supra note 8, at 15 (indicating that in two-thirds of collaborations studied, preclinical development had not yet begun); see also Gregory B. Abbott, Joint Ventures and Collaborative Agreements for Developing and Commercializing Technology in the Life Sciences, 1193 PLI/CORP 247, 252-53 (2000) (noting that over 
identification of targets for drug development in a particular disease area or areas can be part of the collaborative agreement. ${ }^{17}$ When collaboration is this close, the collaborators share not only pre-clinical and clinical R\&D costs but also the overall profits from the drugs developed. ${ }^{18}$ The downstream pharmaceutical company may also buy an equity stake in the upstream company. ${ }^{19}$

The industry has also, in recent years, seen a substantial level of horizontal merger activity. A significant number of prominent pharmaceutical companies, including Novartis, GlaxoSmithKline, and Aventis, are products of horizontal mergers that have occurred over the last few years. ${ }^{20}$ In addition, there has been some merger activity that is both horizontal and vertical in nature. Integrated companies such as Millennium and Abgenix that have both upstream and downstream research capabilities have lately been acquiring upstream companies, thereby increasing their vertical strength. $^{21}$

This increased level of integration through alliance formation or merger raises the question of what type of industry structure is best suited for biopharmaceutical innovation. Arguments that address the relationship between industry structure and innovation tend to divide into two catego-

half of the $\$ 1.9$ billion in strategic alliance revenues earned by the one hundred leading pre-commercialization biotechnology companies in 1999 came from licensing of "platform" technologies); id. at 252 (discussing "broad-based small molecule alliance" between Bayer and Millennium); Millennium Pharmaceuticals, Inc., About Millennium Pharmaceuticals, Inc. Alliances, at http://www.mlnm.com/about/alliances (last visited Apr. 21, 2001) (discussing eleven alliances between Millennium and various pharmaceutical companies, including Wyeth-Ayerst, Aventis, Bayer, and Eli Lilly); The Genomics Payoff, supra note 6 (discussing research alliances with pharmaceutical companies formed by biotechnology companies like CuraGen and Genome Therapeutics).

17. Lisa Jarvis, Bayer, CuraGen in \$1.5 Billion Drug Deal, CHEM. MKT. RPTR., Jan. 22, 2001, at 3 (reporting that collaboration between Bayer and CuraGen includes identification of targets in areas of obesity and diabetes).

18. Id. (noting that Bayer/CuraGen deal involves "shared risks resulting in shared rewards").

19. See, e.g., Andrew Pollack, Bayer and CuraGen in $\$ 1.5$ Billion Pact to Develop Drugs, N.Y. TIMES, Jan. 17, 2001, at C3 (discussing Bayer's acquisition of an equity stake in CuraGen).

20. See David A. Balto \& James F. Mongoven, Antitrust Enforcement in Pharmaceutical Industry Mergers, 54 FoOD DRUG L.J. 255, 255 (1999) (noting that "[t]he pharmaceutical industry is in the midst of a wave of consolidation").

21. See Van Brunt, supra note 15; see also Pamela Sauer, Wall Street Gives Biotech a Shot in the Arm, CHEM. MKT. REP., Mar. 12, 2001 (citing analyst predictions that reduced available cash will lead to greater numbers of mergers and acquisitions in the biotechnology sector in 2001). 
ries: those that extol the virtues of concentration and those that valorize the role of competition. The former view, often associated with the work of economist Joseph Schumpeter, holds that entities with monopoly or quasi-monopoly power are the major engines of innovation. ${ }^{22}$ The Schumpeterian perspective posits that monopoly profits give firms security, and therefore freedom to innovate, in a manner not available to nonmonopoly firms. In addition, monopoly power may help firms appropriate more fully the benefits of their efforts by limiting opportunities for diffusion of knowledge to competitors. The Schumpeterian wisdom is challenged by (inter alia) Kenneth Arrow, who argues that competition is essential to innovation, particularly where intellectual property protection for the downstream product is available and the downstream product would substitute for a product already produced by the monopolist. ${ }^{23}$

This debate in the economic literature finds a parallel in the patent literature. Patent scholar Edmund Kitch has argued that broad, monopolyconferring patent rights on "prospects"- that is, upstream research far removed from commercial use-are necessary for two reasons: first, to provide incentives for development by allowing the firm that owns the prospect to appropriate fully the benefits of such development; and second, to allow the prospect owner to coordinate development efforts, thereby reducing duplicative investment in development. ${ }^{24}$ By contrast, other patent

22. For discussion of the work of Joseph Schumpeter, see infra Part II.A.

23. For discussion of Kenneth Arrow's work, see infra Part II.A.

24. See Edmund W. Kitch, The Nature and Function of the Patent System, 20 J.L. \& ECON. 265, 276 (1977). Suzanne Scotchmer and Howard Chang have also suggested a relatively broad patent scope for basic invention. See Scotchmer, supra note 4; Chang, supra note 4. Their arguments differ significantly from Kitch's, however, in that Scotchmer and Chang focus on the need to provide incentives for the initial production of such invention, which (as they point out) may have social value that far exceeds its "standalone" commercial value. Scotchmer, supra note 4, at 31; Chang, supra note 4, at 48-49. As such, their arguments bear a family resemblance to arguments that Kenneth Arrow and others have made in favor of public funding of basic research, to the effect that private markets will underproduce such research because its social value exceeds its appropriable private value. See Scotchmer, supra note 4, at 39; Chang, supra note 4, at 49 (noting alternative of public funding). Rather than rely on public funding, the proposals by Scotchmer and Chang attempt to make more of this social value privately appropriable through the patent system. In the biopharmaceutical area, however, a large proportion of research that has long-term significance for product development is already funded publicly. See Iain Cockburn \& Rebecca Henderson, Public-Private Interaction in Pharmaceutical Research, 93 PROC. NAT'L ACAD. SCI. USA 12725, 12726 (1995) (determining that publicly funded research was a "critical contributor" to the discovery of almost all of the twenty-five most important drugs introduced between 1970 and 1995); Francis Narin et al., The Increasing Linkage Between U.S. Technology and Public Science, 26 RES. POL'Y 317,318 (1997) (noting that 50 percent of the scientific research cited in drug and 
theorists, including Robert Merges and Richard Nelson, have argued that although coordination of research by a single patentee may slightly reduce duplication, swift progress in innovation requires competition. ${ }^{25}$

In contrast with patent law and general economic theory, antitrust law has traditionally had little to say about innovation. In the past, antitrust law has generally focused on competition in goods markets, and not on the relationship between competition and innovation. ${ }^{26}$ In recent years, however, the traditional rules have been overturned. Antitrust law has begun to focus not only on innovation but also on the question of what market structure might provide the appropriate conditions for innovation. Officials from the Antitrust Division of the Justice Department have written about the need for antitrust law to adopt innovation markets analysis, which focuses on preserving competition not only in end-product markets but also in the R\&D processes that produce end products. ${ }^{2 f}$ Similarly, antitrust guidelines for the licensing of intellectual property adopted by the Justice Department and the FTC have emphasized the innovation markets paradigm. ${ }^{28}$

The issue of whether concentration or competition is the best path for innovation has been discussed with particular vigor and sophistication in the context of the highly publicized Microsoft antitrust case, and in the

medicine patents was funded by the U.S. government). Moreover, public funding of the most basic research is probably superior to broad patent protection in that public funding leaves open the possibility of multiple development paths for the research. See infra Part III.A-B. Even when the upstream research is not publicly funded, it is often relatively inexpensive to generate. Thus, although this Article considers incentives for initial production, it focuses on subsequent development.

25. See Robert P. Merges \& Richard R. Nelson, On the Complex Economics of Patent Scope, 90 COLUM. L. REV. 839, 843-44 (1990) (noting that "[w]ithout extensively reducing the pioneer's incentives, the law should attempt at the margin to favor a competitive environment for improvements, rather than an environment dominated by the pioneer firm"). Merges and Nelson also argue that, as an empirical matter, they could not find a single case where the holder of a broad patent used it effectively through tailored licensing to coordinate the R\&D of others. Id. at 875 . Merges and Nelson do not discuss how many competitors are necessary. Although some commentators have suggested a number greater than four or five, see, e.g., infra note 57, it suffices for these purposes to note that more than one competitor should exist.

26. See George Hay, Innovations in Antitrust Enforcement, 64 ANTTrRUST L.J. 7, 8 (1995) ("Traditional merger analysis has generally featured static analysis of price and output because that is where the anticompetitive consequences of the conduct under scrutiny are expected to occur.").

27. See infra note 48.

28. Id. 
context of the digital industries more generally. ${ }^{29}$ Thus far, however, innovation theorists in antitrust law have paid less attention to the biopharmaceutical industry. ${ }^{30}$ This relative inattention is somewhat curious. Patent rights, which figure prominently in this industry, offer stronger protection (and hence tend to threaten competition more directly) than the copyright claims that have, at least historically, been central to the digital industries. ${ }^{31}$ No doubt one reason for the relative inattention is that the intellectually knotty issue of network externalities, ${ }^{32}$ which leads to standardization and can significantly accelerate concentration (as well as produce troublesome lock-in effects), has not yet been raised in biopharmaceutical development. ${ }^{33}$ Moreover, in the biopharmaceutical arena, no firm cur-

29. See, e.g., Howard A. Shelanski \& J. Gregory Sidak, Antitrust Divestiture in Network Industries, 68 U. CHI. L. REV. 1 (2001); Thomas A. Piraino, Jr., Identifying Monopolists' Illegal Conduct Under the Sherman Act, 75 N.Y.U. L. Rev. 809 (2000); Ronald A. Cass \& Keith N. Hylton, Preserving Competition: Economic Analysis, Legal Standards and Microsoft, 8 GEO. MASON L. REV. 1 (1999); Symposium, The Changing Face of Efficiency, 7 GEO. MASON L. REV. 485 (1999).

30. A notable exception is John Barton, who has written a series of very useful articles on the intersection of patent law and antitrust in biotechnology, particularly in the context of sequential innovation. See, e.g., John H. Barton, Patents and Antitrust: $A$ Rethinking in Light of Patent Breadth and Sequential Innovation, 65 ANTITRUST L.J. 449 (1997). In addition, an interesting recent article by Jonathan Barnett discusses innovation markets in the biopharmaceutical industry. Jonathan M. Barnett, Cultivating the Genetic Commons: Imperfect Patent Protection and the Network Model of Innovation, 37 SAN DIEGO L. REV. 987 (2000). For a discussion of Barnett's article, see infra note 64.

31. To be sure, patent law is becoming increasingly important in the digital industries, particularly in the area of computer software. See generally Julie E. Cohen \& Mark A. Lemley, Patent Scope and Innovation in the Software Industry, 89 CALIF. L. REV. 1 (2001).

32. Network externalities arise in a given product market if the utility that a consumer derives from use of the product increases as the number of other consumers who use the product increases. See generally Mark A. Lemley \& David McGowan, Legal Implications of Network Economic Effects, 86 CALIF. L. REV. 479 (1998).

33. With the advent of genomics, which merges digital technology and biotechnology, information regarding genes and their protein products has become valuable not only in biochemical form but also in digital form. Numerous companies license databases of such information as trade secrets. Moreover, at least one company has filed a patent application on DNA sequence information stored in a computer chip. See Eisenberg, supra note 5, at 793 (discussing Human Genome Sciences' patent application for the DNA sequence of $\mathrm{H}$. influenzae, stored in computer-readable medium). Arguably, network externality issues might arise if a standardized platform for viewing and manipulating computerized genetic and protein data becomes highly desirable. See Scott Hensley, Software Will Play Big Role in Genome Research, WALL ST. J., Feb. 14, 2001, at B16 (noting argument that the key to development of genomics is user-friendly interfaces-"new genome browsers that are akin to Internet Explorer offered by Microsoft Corp."). In 
rently has market power comparable to that of Microsoft. Rather, there exist approximately twenty significant pharmaceutical companies and about fifty biotechnology companies with market capitalization of at least $\$ 1$ billion. ${ }^{34}$ Nonetheless, as noted above, we are beginning to see significant consolidation, both vertical and horizontal, in the industry. It is therefore important to think proactively about which types of consolidation (if any) will foster innovation in the industry. One of the more salient features of biopharmaceutical innovation is the length, expense, and risk of the cumulative process that leads to a drug that is patentable and ready for clinical testing. On average, this process takes two to five years and can cost tens, if not hundreds, of millions of dollars. ${ }^{35}$ Given the length and expense of the process, and the knowledge spillovers that may result, the patent that is ultimately received on the end-product drug does not necessarily appropriate the full value of the R\&D expended. At a minimum, there may be significant uncertainty about whether a drug patent that captures the full value of R\&D will issue. Thus the biopharmaceutical sector is, to some extent, tailor-made for the Schumpeterian/Kitchean thesis, which emphasizes the importance of broad, monopoly-conferring patent rights ${ }^{36}$ in incentivizing the $R \& D$ process by allowing appropriation of its full value.

In this Article, I embrace the proposition that, given the high cost associated with biopharmaceutical $R \& D$ and the difficulty of recovering all of that cost in an end-product drug patent, relatively upstream patent rights

that context, a company that could copyright such a standard might achieve market power by virtue of network externalities. That topic is, however, beyond the scope of this paper.

34. Van Brunt, supra note 15.

35. Because the drug therapy being tested is almost always the subject of patent protection, the arduous clinical testing process does not argue in favor of patenting upstream research. It also bears mention that, in the not-too-distant future, the cost of preclinical development (and clinical development for that matter) may be reduced by the integration of digital technology into drug development. See generally Rai, supra note 3.

36. Monopoly power has been defined as "the power to control prices or exclude competition." United States v. E.I. duPont de Nemours \& Co., 351 U.S. 377, 391-392 (1956). Patents do not always, or even generally, convey monopoly power. Indeed, the presumption that monopoly power follows from a patent right is one that scholars and courts must resist. See Edmund Kitch, Elementary and Persistent Errors in the Economic Analysis of Intellectual Property, 53 VAND. L. REV. 1727, 1729-1739 (2000). Cf. Jefferson Parish Hosp. Dist. v. Hyde, 466 U.S. 2 (1984) (suggesting such a presumption). However, broad patents on upstream research can convey a type of monopoly power over the research and development process. Indeed, Kitch himself has asserted that his theory of cumulative innovation may "clarify the process and conditions under which a monopolistic industry will be more efficient than a competitive one." Kitch, supra note 24, at 286 (emphasis added). 
may have a role to play in promoting innovation. Nonetheless, I argue that because multiple independent research paths are important for promoting creative development of early-stage research, competition must also play a role.

The question then becomes one of how the law, specifically patent and antitrust law, should be deployed in order to preserve sufficient competition. In some industries, particularly industries characterized by network externalities, antitrust may have a significant role to play. In those industries, even intellectual property rights that are relatively weak may not forestall the possibility of monopoly concentration. By contrast, in the area of biopharmaceuticals, broad patent rights provide the primary mechanism by which an anticompetitive situation might arise. This industry-specific reality places particular pressure on the patent system. After all, if we can narrow the reach of the patent law in a manner that does not unduly hamper innovation incentives, we can largely avoid the need for antitrust intervention. Indeed, if patent content and scope are defined carefully, many of the remaining impediments to innovation will involve situations where it is necessary to aggregate patent rights, not disperse them. The only significant context in which antitrust analysis based on innovation markets theory will need to impose procompetitive conditions on patent aggregation will arise when the aggregation threatens to give a private party broad control over a promising upstream technology.

Part II of this Article briefly outlines and discusses the rival theories of cumulative innovation noted above. Part III then analyzes the application of these theories to the current structure of the biopharmaceutical industry, arguing that some level of competition (i.e., two or more firms in any given area of innovation) is essential. It also points to restrictions on the content and scope of patent protection that could be used to encourage competition. Finally, Part IV addresses the dual role that antitrust law should play in working to encourage aggregation under certain circumstances and discourage it under other circumstances.

\section{CONCENTRATION VERSUS COMPETITION: THE BACKGROUND THEORY}

\section{A. Economic and Patent Perspectives}

Monopoly theorists favor concentration as a means of promoting innovation. The basic tenets of monopoly theory are manifested in both Schumpeter's general thesis on innovation and Kitch's more patentspecific prospect argument. The Schumpeterian view on innovation is relatively straightforward. Monopolies foster innovation, particularly risky 
innovation, because they can appropriate fully (or at least more fully than competitive markets) the surplus generated by such investment. ${ }^{37}$ Relatedly, the possibility of a monopoly rate of return should attract capital investment and provide a hedge against loss. Schumpeter also argues that because monopolies are always susceptible to challenges by new technology, those monopolies that become complacent about innovation are likely to be replaced by new monopolies. ${ }^{38}$ Although Schumpeter's work does not focus on intellectual property, the prospect theory put forward by Kitch suggests a mechanism by which intellectual property can convey a type of monopoly right, at least in the context of R\&D. As Kitch notes, broad patents, granted early in the development process, should give the patentee control over future development. ${ }^{39}$ Kitch's argument about the need for monopoly rights very much follows Schumpeter's. According to Kitch, absent patent protection of nascent invention, no one would invest in subsequent development of the invention for "fear that the fruits of the investment [would] produce unpatentable information appropriable by competitors." Kitch also argues that granting broad property rights on nascent invention will allow the rightsholder to coordinate subsequent development efficiently: because all potential developers will have to identify themselves to the rightsholder before they begin such development, the rightsholder will be able to eliminate duplicative investments in development and facilitate the exchange of information among developers. ${ }^{40}$ Mark Grady and Jay Alexander have made the related argument that granting patent rights early in the development process reduces the possibility of rent-dissipating patent races. ${ }^{41}$ In particular, nascent invention that "signals" many different, possibly patentable, improvements should be given a broad scope so as to avoid the possibility of races to patent these improvements. ${ }^{42}$

37. See generally JoSEPH A. SCHUMPETER, CAPITALISM, SOCIALISM AND DEMOCRACY 81-106 (1942).

38. Id. at 83 (arguing that the pursuit of market power is a creative force that "incessantly revolutionizes the economic structure from within, incessantly destroying the old one, incessantly creating a new one").

39. Kitch, supra note 24 , at 276.

40. Id. Kitch's argument appears to ignore the possibility that, under current patent doctrine, a second-generation inventor can secure an improvement patent without negotiating a license from the initial patentee. However, to the extent that Kitch's is a normative (as contrasted with descriptive) theory of the patent law, his omission is not crucial.

41. See Mark F. Grady \& Jay I. Alexander, Patent Law and Rent Dissipation, 78 VA. L. REV. 305, 318 (1992).

42. Id. at 310 . Obviously enough, both of the problems identified by prospect theorists-underinvestment in innovation and duplicative investment in innovation-cannot occur simultaneously. Presumably underinvestment arises if the innovation is unlikely to 
In contrast with monopoly theorists, advocates of competition argue that innovation incentives are often smaller under monopolistic conditions than under competitive conditions. For example, as Arrow has emphasized, if a new or superior product would cannibalize the market for the monopolist's existing product, the monopolist will have no incentive to create that product. ${ }^{43}$ By contrast, in competitive markets, there is no impediment to the creation of new products, particularly if these new products, once created, can be the subject of intellectual property protection. Moreover, although competition may lead to some duplicative investment, at least some of the redundancy may be more apparent than real. As Merges and Nelson have emphasized, because the different possible goals of improvement are often unknown at the time such improvement starts, "racing" among competitors may yield results that would not have emerged if work on improvement had been restricted to a single party (or even to a few parties). ${ }^{44}$ Indeed, even if we assume that a clear improvement or development goal can be established at the outset, and that all research is directed to the pursuit of that goal, innovators may take different approaches to reach the same goal. These different approaches may prove to have independent social value.

Additional support for the competition argument can be found in the literature on organizational behavior. To the extent that a firm with monopoly power is relatively large, ${ }^{45}$ the firm's hierarchical structure and culture may be inimical to innovation, or at least inimical to radical innovation. ${ }^{46}$ Innovation incentives may also be weak in a large firm because it is difficult to design compensation schemes that accurately reflect responsibility for innovative inputs. ${ }^{47}$

yield patents, while overinvestment arises if innovation is likely to yield patents. Given the uncertainty associated with innovation, however, innovators are not likely to know with any precision whether their work will be patentable or not. By contrast, Kitch's theory appears to presume that innovators will have this foresight.

43. See generally Kenneth J. Arrow, Economic Welfare and the Allocation of Resources for Innovation, in THE RATE AND DIRECTION OF INVENTIVE ACTIVITY 609-25 (Nat'l Bureau of Econ. Research ed., 1962).

44. As a consequence, innovation may not be perfectly modeled as a race or common pool problem. See Merges \& Nelson, supra note 25, at 873-74 (discussing limitations of race and common pool models).

45. Although size often correlates with monopoly power, they are two independent variables.

46. See Barnett, supra note 30, at 1024-26 (collecting sources from organizational behavior literature).

47. See Oliver E. Williamson, The Economic Institutions of Capitalism 4142 (1985); see also Barnett, supra note 30, at 1022-24 (collecting sources on "managerial risk aversion"). 


\section{B. Innovation Markets Theory}

As noted earlier, antitrust law has, in recent years, begun to take up the question of innovation. In particular, Arrow's work has heavily influenced the innovation markets approach to antitrust enforcement, an approach adopted during the Clinton Administration by the Antitrust Division of the Department of Justice and the FTC. ${ }^{48}$ As defined by the Justice Department and the FTC, an innovation market consists of the research and development directed to particular new or improved goods or processes, and the close substitutes for that research and development. ${ }^{49}$ Close substitutes are those R\&D efforts, technologies, and goods that significantly constrain the exercise of market power with respect to the relevant research and development, for example by limiting the ability and incentive of a hypothetical monopolist to retard the pace of research and development. ${ }^{50}$ In contrast with antitrust analysis of product markets, there are no geographic limitations on innovation markets analysis. ${ }^{51}$ As indicated by the various written pronouncements of the Justice Department and the FTC, and by the agencies' actual application of the analysis, innovation markets analysis can be applied to horizontal mergers, joint ventures that fall short of a merger, or various types of intellectual property licensing. ${ }^{52}$ If a particular merger, joint venture, or licensing agreement unduly limits the number of competitors in a particular innovation market and yields no offsetting effi-

48. See Richard J. Gilbert \& Steven C. Sunshine, Incorporating Dynamic Efficiency Concerns in Merger Analysis: The Use of Innovation Markets, 63 ANTITRUST L.J. 569 (1995) [hereinafter Gilbert \& Sunshine, Incorporating Dynamic Efficiency Concerns in Merger Analysis]; see also Richard J. Gilbert \& Steven C. Sunshine, The Use of Innovation Markets: A Reply to Hay, Rapp, and Hoerner, 64 ANTITRUST L.J. 75, 76 (1995) [hereinafter Gilbert \& Sunshine, The Use of Innovation Markets] (noting influence of Arrow's theory on why a monopolist has less incentive to invest in innovation than firms in a competitive industry); U.S. Dep't of Justice \& FTC, Antitrust Guidelines for the Licensing of Intellectual Property $\$ 3.2 .3$ (1995), http://www.usdoj.gov/atr/public/ guidelines/ipguide.htm [hereinafter Licensing Guidelines] (defining innovation markets). At the time they wrote the 1995 article, Gilbert and Sunshine were Deputy Assistant Attorneys General in the Antitrust Division of the Department of Justice.

49. Licensing Guidelines, supra note $48, \S 3.2 .3$.

50. Id.

51. See Gilbert \& Sunshine, Incorporating Dynamic Efficiency Concerns in Merger Analysis, supra note 48, at 594-95.

52. See id. (discussing mergers and joint ventures); Licensing Guidelines, supra note 48 (discussing licensing and joint ventures); see also Balto \& Mongoven, supra note 20 (discussing the FTC's application of innovation markets analysis to pharmaceutical mergers). The issue of whether joint ventures between horizontal competitors should be treated differently from mergers is one I address infra note 132-33 and accompanying text. 
ciencies in terms of the use of $R \& D$ to promote innovation, restrictions may be placed on the transaction. ${ }^{53}$

To say that innovation markets analysis has been controversial among antitrust scholars would understate the point considerably. Some of the controversy has revolved, however, around questions that are not central to the analysis in this Article. For example, one point of contention has been whether the innovation markets approach can find a plausible doctrinal foundation in existing antitrust law. ${ }^{54}$ For purposes of this paper, I assume that innovation markets analysis does have a doctrinal foundation (or that such a doctrinal foundation can be found). ${ }^{55}$ Putting this question to one side, however, several important issues remain. One issue of particular importance, to which I will return in Part IV, involves the question of whether innovation markets can be defined with any degree of accuracy, particularly in the paradigmatic case where no goods market currently exists. ${ }^{56}$ In addition, there is of course the fundamental question of whether innovation is in fact hindered by concentration, or, in other words, benefited by competition.

In the abstract, it is very difficult to resolve the competing arguments regarding whether concentration is a spur to innovation or an impediment thereto. Moreover, empirical evidence on the general question is relatively sparse and equivocal. Although studies by F.M. Scherer have suggested that there is a negative correlation between high levels of concentration

53. Gilbert \& Sunshine, Incorporating Dynamic Efficiency Concerns in Merger Analysis, supra note 48, at 594-97 (outlining "a Rough Guide to the Innovation Markets Approach" in merger and joint venture contexts). Similarly, the intellectual property licensing guidelines apply to innovation markets. Given the terms of the analysis, it is not surprising that it yields few, if any, per se rules. Indeed, according to Gilbert and Sunshine, the regulator should not always assume that a monopolist will reduce $R \& D$ effort. They note that, if the monopolist wants to enter new markets where it does not presently compete, that motivation may militate against reducing R\&D. See id. at 596.

54. See Robert J. Hoerner, Innovation Markets: New Wine in Old Bottles, 64 ANTITRUST L.J. 49, 50-55 (1995) (arguing that innovation markets do not exist under current antitrust doctrine).

55. The likelihood that a doctrinal foundation can be found is substantial given the extremely broad language of the antitrust statutes, particularly the Sherman Act. See, e.g, RICHARD POSNER, ANTITRUST LAW: AN ECONOMIC PERSPECTIVE 7 (1976) (noting that "the body of antirust doctrine is largely the product of judicial interpretation of the vague provisions of the antitrust laws ...").

56. I call the case where a goods market does not exist the paradigmatic case because in other cases innovation markets analysis may overlap with the potential competition doctrine, which examines the potential emergence of competition in existing goods markets. See Hay, supra note 26 , at 13-14. 
and expenditure on $\mathrm{R} \& \mathrm{D},{ }^{57}$ other studies indicate that this effect may depend on the particular industry under consideration. ${ }^{58}$ Thus, even proponents of competition in innovation note that analysis of the issue should be industry-specific. ${ }^{59}$ An industry-specific approach is also important in any patent-based analysis. As numerous empirical studies have pointed out, the importance of patents as a mechanism for appropriating the value of R\&D varies from industry to industry. ${ }^{60}$ Therefore, in the next part I turn to the specific case of competition versus concentration in the biopharmaceutical industry.

\section{CUMULATIVE INNOVATION IN BIOPHARMACEUTICALS: THE ROLE OF COMPETITION}

\section{A. Arguments in Favor of Broad Upstream Rights}

In the specific context of the biopharmaceutical industry, the claim that broad, monopoly-conferring rights on nascent invention can provide a necessary spur to further innovation may well have merit. ${ }^{61}$ As matters

57. F.M. SCHERER, INNOVATION AND GROWTH: SCHUMPETERIAN PERSPECTIVES 247 (1984) (noting that "technological vigor appears to increase with concentration mainly at relatively low levels of concentration. When the four-firm concentration ratio exceeds 50 or 55 percent, additional market power is probably not conducive to more vigorous technological efforts and may be downright stultifying.").

58. See Richard C. Levin et al., $R \& D$ Appropriability, Opportunity, and Market Structure: New Evidence on Some Schumpeterian Hypotheses, 75 AM. ECON. REV. 20 (1985).

59. Gilbert \& Sunshine, Incorporating Dynamic Efficiency Concerns in Merger Analysis, supra note 48, at 580 ("Whatever relationship exists at a general economywide level between industry structure and $R \& D$ is likely masked by differences across industries in technological opportunities, demand, and the appropriability of inventions.").

60. See, e.g., Wesley Cohen et al., Protecting TheIR INTEllectual Assets: APPROPRIABILITY CONDITIONS AND WHY U.S. MANUFACTURING FIRMS PATENT (OR NoT) (Nat'l Bureau of Econ. Research, Working Paper No. 7552, 2000) (discussing the importance of patents relative to other mechanisms of appropriation across various industries and concluding that patents are particularly important in the pharmaceutical area); Richard C. Levin et al., Appropriating the Returns from Industrial Research and Development, in 3 BROOKINGS PAPERS ON ECONOMICS ACTIVITY 783 (Martin N. Baily et al. eds., 1987).

61. It is important to emphasize, however, that the argument for broad protection of early-stage biopharmaceutical invention is conceptually distinct from the argument for broad protection of end-product drugs. Thus, the ample empirical evidence that patents on end-product drugs are important, see Cohen et al., supra note 60; Levin et al., supra note 60 , does not bear upon the empirical case for patents on early-stage invention. 
currently stand, ${ }^{62}$ the research path from initial discovery of a potentially relevant DNA sequence or receptor to identification of a drug that is ready for clinical testing can be quite risky, lengthy, and expensive. ${ }^{63}$ If the initial discovery is not protected by a broad patent, the $R \& D$ path may produce knowledge that is appropriable by competitors. ${ }^{64}$

62. See supra note 35 (discussing efficiencies that may be produced by genomics).

63. Thus, for example, only 10 percent of drug compounds tested at the preclinical stage pass to the clinical testing stage. See Michael J. Malinowski \& Maureen A. O'Rourke, A False Start? The Impact of Federal Policy on the Genotechnology Industry, 13 YALE J. ON REG. 163, 206-208 (1996) (discussing the drug approval process). In fact, some commentators have justified the substantially relaxed (and doctrinally anomalous) standard of nonobviousness that the Federal Circuit applies in the biotechnology area by pointing to the risk and expense of biotechnological innovation. See Robert P. Merges, One Hundred Years of Solicitude: Intellectual Property Law, 1900-2000, 88 CALIF. L. REV. 2187, 2225-2226 (2000); see also Karen I. Boyd, Nonobviousness and the Biotechnology Industry: A Proposal for a Doctrine of Economic Nonobviousness, 12 BERKELEY TECH. L.J. 311 (1997). It is important to emphasize, however, that in many of the cases in which the Federal Circuit has applied the nonobviousness requirement leniently, the economic argument applied most clearly to the economic difficulty of developing the earlystage biotechnological inventions, not to the economics of producing them in the first instance. It also bears mention that if the Federal Circuit is in fact applying economic analysis, it should do so explicitly. Its failure to give any hint of an economic policy rationale not only muddies the doctrinal waters (requiring as a matter of doctrinal logic, for example, that the court adopt an excessively cramped view of claim scope in biotechnology, see Arti K. Rai, Intellectual Property Rights in Biotechnology: Addressing New Technology, 34 WAKE FOREST L. REV. 827, 831-37 (1999); see also infra note 103), but it also forestalls any evaluation of precisely how the Federal Circuit is using the economic rationale.

64. In a provocative recent article, Jonathan Barnett argues that weak patent rights which do not confer full appropriability can nonetheless provide incentives to innovate that are just as strong as those provided by broad patents. See Jonathan M. Barnett, supra note 30. Although I endorse weak patents on the most basic research on the grounds that weak patents do not interfere with the multiple research paths that are necessary for the development of such research, see infra Part III.A-B, there is reason to question Barnett's optimistic assertion that we can "transcend" the Schumpeterian debate," Barnett, supra note 30 , at 1031 , because weak patents can generate incentives to develop that are just as strong as those generated by broad patents. Barnett first argues that, as an empirical matter, biopharmaceutical research has proceeded expeditiously even with relatively narrow patents. Id. at 1008 . However, the fact that biopharmaceutical research may have proceeded expeditiously (a contestable proposition in and of itself) does not say anything about whether such research would have proceeded even faster with broad patents. In addition, Barnett makes the theoretical argument that because weak upstream patents "generally cover only part of the innovation's spillover applications, and sometimes only part of the development costs," id. at 1011, they encourage upstream researchers to collaborate with downstream firms in order to appropriate at least some (although, given the weak patent, by no means all) of the spillover applications of the patented research. Barnett's argument focuses on the incentives weak patents may give to the upstream re- 
Other arguments stemming from the collaborative nature of the biopharmaceutical industry provide further support for broad rights. For example, in the context of a research collaboration between an upstream biotechnology company and a downstream pharmaceutical firm, broad rights may be useful if they give the upstream partner the bargaining power necessary to control the direction of the collaboration. ${ }^{65}$ Empirical analysis of collaboration between biotechnology and pharmaceutical firms indicates that such collaboration is more likely to be successful when the upstream partner has greater control. ${ }^{66}$ Moreover, to the extent that small biotechnology firms own broad upstream rights, any concentration produced by such rights is unlikely to create excessive risk-aversion (as it might, for example, in the context of large firms). ${ }^{67}$ In addition, if upstream compa-

searcher. It does not address the downstream developer's incentives, which are the focus of Kitch's theory (and appropriately so, given that downstream developers are likely to supply much of the capital for development). Both theory and conventional wisdom suggest that collaboration might be more attractive to downstream firms when the development process does not create unpatentable spillovers (i.e., the broad upstream patent situation) than when it does (i.e., the weak patent situation). See, e.g., Andrew Pollack, Weed-Out Time in Biotechnology, N.Y. TIMES, Dec. 16, 1998, at C1, C8 (noting industry wisdom that strong patents attract equity financing, including financing from pharmaceutical companies).

65. See generally LERNER \& MERGES, supra note 8 (discussing correlation between bargaining power and control of research). Broad upstream patents may confer bargaining power either directly or by allowing the upstream partner to attract equity financing that enhances its bargaining position. See, e.g., Pollack, supra note 64, at C1, C8; Josh Lerner, The Importance of Patent Scope: An Empirical Analysis, 25 RAND J. ECON. 319, 325-26 (1994) (observing that broad patents helped biotechnology companies attract venture capital).

66. JOSH LERNER \& AleXANDER TSAI, DO EQUTTY FinANCING CyCles MATTER? EVIDENCE FROM BIOTECHNOLOGY ALLIANCES 20-21 (Nat'l Bureau of Econ. Research, Working Paper No. 7464, 2000).

67. See supra notes 45-47 and accompanying text. Indeed, it is not clear that even large companies in a concentrated biopharmaceutical industry would be excessively riskaverse. Because "big pharma" is always concerned about the generic competition that ensues once patent rights have expired, it is necessarily concerned with developing new patented products. Relatedly, "big pharma" may be less concerned than firms in other industries with cannibalizing existing products, as these products will lose their patent protection in a defined period of time in any event. On the other hand, we have, in recent years, seen pharmaceutical companies expending substantial amounts of money on extending patent life beyond the term contemplated by Congress and on the production and marketing of "me-too" drugs whose marginal utility is questionable. See generally Rai, supra note 3. Similarly, a 1997 survey of leading researchers in the biosciences determined that 53 percent of respondents thought that pharmaceutical companies were not sufficiently innovative; 33 percent of respondents thought that such companies did not provide research freedom. MCKINSEY \& CO., RAISING INNOVATION TO NEW HEIGHTS IN PhaRMaCeUtiCAL RESEARCH 54 (1997) (on file with author). 
nies own the rights, these companies probably will not fear that innovation will cannibalize existing downstream products. Finally, even if one accepts the argument (and there is good reason to accept it) that multiple research paths are necessary to exploit the full potential of upstream innovation, Kitch's theory does not foreclose the possibility of different research paths. Rather, Kitch posits that the upstream rightsholder would conclude licensing arrangements not simply with one developer but with a number of different developers, ${ }^{68}$ each of whom might be charged with pursuing (or might choose to pursue) a different research path.

\section{B. Why We (Nonetheless) Need Competition}

This last argument-that multiple research paths can be pursued under broad upstream rights through multiple tailored licenses-is the weak link that ultimately undermines Kitch's chain of reasoning. Contrary to Kitch's theory, when patents are licensed in improvement contexts, licensing arrangements can be difficult to conclude. Merges and Nelson have assembled persuasive historical evidence that, in a variety of industries that relied on cumulative innovation, broad patents on initial invention could not be licensed effectively and hence hindered subsequent development. The exact nature of the failure to license differed by industry. In the field of incandescent lighting, Thomas Edison's broad patent covering the use of carbon filament as a source of light slowed down the development of the industry because Edison's company itself did not improve on the patent, and it used the patent to shut down competitors who had designed improved products. ${ }^{69}$ In the case of the Wright brothers' broad patent on a stabilizing and steering system, the patent holders sought to license their patent but could not, even over a period of ten years, work out licensing agreements. ${ }^{70}$ Indeed, the United States' entry into World War I and the consequent pressure by the Army and Navy (who were the prime buyers of aircraft) were necessary to bring about a cross-licensing scheme in the industry. ${ }^{71}$

Similarly, there are indications in the biopharmaceutical industry that development through tailored licensing will be difficult to achieve. Peter Ringrose, the head of $R \& D$ at Bristol-Myers Squibb recently estimated that there were dozens of projects which the company could not pursue because it was unable to conclude the requisite licensing agreements with

68. Kitch, supra note 24, at 276.

69. Merges \& Nelson, supra note 25 , at 886-87.

70. See generally JACOB A. VANDERMEUlen, The Politics of AIRCRAFt 19 (1991).

71. Id. at 21-22, 26; see also Merges \& Nelson, supra note 25 , at 890-91. 
the upstream patent holders. ${ }^{72}$ More generally, an empirical study conducted in 1997 and 1998 by the National Institutes of Health ("NIH") Working Group on Research Tools documented frustration in the biotechnology, pharmaceutical, and academic research sectors with the high transaction costs of licensing negotiations over research tools. Although these transaction cost obstacles could be overcome when a particular licensing arrangement was considered extremely valuable by the parties involved, transaction costs did block the licensing of tools that were perceived as low-value. ${ }^{73}$ On first examination, the inability to conclude licenses on low-value research might not appear disturbing. However, as NIH Working Group Chair Rebecca Eisenberg has pointed out, because parties often fail to predict accurately which research will ultimately be valuable, there is reason to be concerned when even ostensibly low-value transactions do not go forward. ${ }^{74}$

Indeed, in recent years, various pharmaceutical companies and other downstream developers have endeavored to defeat property rights in upstream information by paying to place this information (for example, information on gene fragments as well as information on SNPs) in the public domain. In the mid-1990s, the pharmaceutical company Merck paid Washington University researchers to place gene fragments in the public domain. ${ }^{75}$ More recently, a group of pharmaceutical companies known as the SNP Consortium have been mapping SNPs and placing this genomic information in the public domain on a quarterly basis. ${ }^{76}$ Similarly, several pharmaceutical companies, in conjunction with Affymetrix, a maker of DNA microarrays, are supporting an effort to sequence the mouse genome and place the results in the public domain. ${ }^{77}$ By making upstream research public, downstream developers hope to generate prior art that will, given the novelty ${ }^{78}$ and nonobviousness ${ }^{79}$ requirements of the patent statute,

72. See Andrew Pollack, Bristol-Myers and Athersys Make Deal on Gene Patents, N.Y. TIMES, Jan. 8, 2001, at C2.

73. Rebecca S. Eisenberg, Bargaining Over the Transfer of Proprietary Research Tools: Is This Market Failing or Emerging, in EXPANDING THE BOUNDARIES OF INTELLECTUAL PROPERTY: INNOVATION POLICY FOR THE KNOWLEDGE SOCIETY (Rochelle Dreyfuss et al. eds., forthcoming 2001).

74. $I d$.

75. Rebecca S. Eisenberg, Intellectual Property at the Public-Private Divide: The Case of Large-Scale cDNA Sequencing, 3 U. CHI. L. SCH. RouNDTABLE 557, 559 (1996).

76. See Roberts, supra note 11.

77. Public-Private Project to Deliver Mouse Genome in Six Months, 29 SCI. 242 (2000).

78. See 35 U.S.C. $\$ 102$ (a) (1994) (requiring that, in order for an invention to be patentable, the invention not be "known or used ... or patented or described in a written publication ... . before the invention thereof by the applicant for patent"). 
thwart the ability of upstream developers to obtain patents on the information. $^{80}$

Empirical evidence suggesting the difficulty of achieving development through tailored licensing is in accord with theoretical arguments for why such development might be difficult to attain. Consider first a context that Kitch himself does not consider - the blocking patents situation, where the second-generation inventor comes up with a patentable (that is, novel and nonobvious) improvement on the first-generation invention. Although the second-generation improvement is independently patentable, it nonetheless incorporates the first-generation invention and therefore infringes the first inventor's patent. In order to practice its improvement, the secondgeneration inventor must therefore seek a license from the first-generation inventor. (Conversely, if the first-generation inventor wants to practice the improvement, it must seek a license from the improver.) Ex post, it may be very difficult for such a licensing negotiation to go forward. As Suzanne Scotchmer has argued, in the context of blocking patents on cumulative innovation, it is impossible to divide the surplus ex post in a manner that provides adequate incentives for both the initial inventor and the improver: in general, the improver will not receive a sufficient share of the surplus. ${ }^{81}$ This is especially true where the value of the patented improvement is large relative to that of the initial patented invention. In that case the possibility of strategic bargaining by the initial inventor is quite high. ${ }^{82}$

Of course, ex ante bargaining between the first and second-generation inventors could be used to avoid the bilateral monopoly problem just identified. ${ }^{83}$ Indeed, Kitch's exclusive focus on ex ante agreements suggests that he considers blocking patents to be contrary, as a normative matter, to

79. See 35 U.S.C. $\$ 103$ (1994) (requiring that a patentable invention not be "obvious at the time the invention was made to a person having ordinary skill in the art to which [it] pertains").

80. See Rebecca S. Eisenberg, The Promise and Perils of Strategic Publication to Create Prior Art: A Response to Professor Parchomovsky, $98 \mathrm{MICH}$. L. REV. 2358 (2000) (discussing creation of prior art through publication of such art).

81. See, e.g., Scotchmer, supra note 4, at 34 (noting that in the context of cumulative innovation with two innovators, "the 'natural' system of property rights-requiring every later innovator to license any underlying technology-will on average give deficient incentives for outside firms to develop second generation products").

82. Robert P. Merges, Intellectual Property Rights and Bargaining Breakdown: The Case of Blocking Patents, 62 TENN. L. REv. 75, 79 (1994).

83. By ex ante bargaining, I mean negotiation over arm's-length licensing agreements conducted ex ante. I do not include ex ante agreements in which the parties align their interests more closely by, for example, the formation of a strategic alliance in which both risk and profit are shared. 
the type of patent system he advocates. ${ }^{84}$ Assuming for the purposes of argument that we had a system without blocking patents, could the coordinated licensing advocated by Kitch work? Scotchmer has been a prominent advocate of ex ante agreements as a mechanism for dividing surplus between first and second-generation inventors. ${ }^{85}$ Scotchmer's case for the superiority of ex ante licensing to bargaining between bilateral monopolies is persuasive. However, Scotchmer appears to underestimate the difficulty of concluding even ex ante licensing agreements, at least given the background legal regime. In order to conclude an agreement ex ante, the improver would have to reveal information about its potential improvement to the first inventor. The improver may be reluctant to do so because at the time it is revealed, this information would be protectable against improper appropriation only through trade secret law, which is a rather weak form of protection. ${ }^{86}$ Moreover, even if trade secret law could protect perfectly against misappropriation, ex ante bargaining over the direction of upstream research would be subject to a great amount of uncertainty. Disagreement about the value of the patented invention relative to the value of the improvement might make it very difficult for the negotiating parties to reach an agreement. As Heller and Eisenberg have emphasized, such disagreement is particularly likely in the context of upstream molecular biology research because the negotiating parties are often scientists who may overestimate the value of their scientific contribution. ${ }^{87}$

One could argue that the difficulty with Kitch's approach is not that it favors broad rights but rather, that it assumes development of such rights

84. Notably, copyright doctrine, which does not have a role for "blocking copyrights," provides a better model for Kitch's theory than does patent doctrine. See Mark A. Lemley, The Economics of Improvement in Intellectual Property Law, 75 TEX. L. REV. 989 (1997).

85. Scotchmer, supra note 4 , at 35 . Scotchmer does note, however, that the optimal solution is not an ex ante agreement but, rather, complete vertical integration. Id. (arguing that the "solution to the incentive problem would be to integrate all possible innovators into one firm before even the first innovator has invested"); see also Jerry R. Green \& Suzanne Scotchmer, On the Division of Profit in Sequential Innovation, 26 RAND J. ECON. 20, 31 (1995) ("Ex ante agreements have the potential to increase the expected profits of both parties without inhibiting later research, but even with ex ante agreements, the first innovator cannot collect all the profit from second-generation improvement.").

86. The problem identified here has been discussed extensively and is termed Arrow's information paradox. For discussion of this paradox, see, for example, Lemley, supra note 84, at 1050-51; see also Robert Merges, supra note 82, at 81-82.

87. See Michael Heller \& Rebecca S. Eisenberg, Can Patents Deter Innovation? The Anticommons in Biomedical Research, 280 SCI. 698, 701 (1998) (making arguments that natural scientists may have self-serving biases due to commitments to research hypotheses and that they may also have a difficult time gauging probabilities of success). 
will occur through licensing rather than through vertical integration. After all, licensing (even ex ante licensing) entails steep transaction costs, and movements toward vertical integration can reduce transaction costs, at least over the long term. ${ }^{88}$ Moreover, with vertical integration, the developer does not have to pay a supracompetitive price for the patented input and can thus reduce total R\&D costs. ${ }^{89}$ Similarly, Scotchmer's extensive research suggests that vertical integration may be the optimal regime for sequential innovation because vertically integrated parties do not need to divide surplus. ${ }^{90}$ Kitch's overall thesis in favor of broad upstream rights might therefore work in contexts where such vertical integration (or arrangements functionally close to vertical integration) could be implemented. Indeed, in an interesting recent article, John Duffy makes precisely this argument. ${ }^{91}$ Duffy also provides empirical support for his argument, drawing upon the examples of xerography, zippers, cellophane, and safety razors. ${ }^{92}$ According to Duffy, improvements in each of these industries progressed quickly after the pioneer patent holder achieved some level of vertical integration with subsequent developers.

However, if in keeping with Kitch's theory, upstream patent rights are extremely broad, such that only a few vertically integrated firms exist, vertical integration considerably narrows the number of different research avenues that are likely to be pursued. Not only is a single vertically integrated firm likely to be relatively large, and hence possibly risk averse and lacking in creativity, but it is also unlikely to license its upstream research to other developers who may pursue alternate research paths. Such licensing would create the very transaction costs that integration was intended to eliminate. It would also be likely to yield competing end products. Notably, none of the products cited by Duffy depended on highly upstream research. Rather, in each example the ultimate commercial manifestation of the pioneer patent was fairly clear. In the case of xerography, for example,

88. See Oliver E. WILliamson, The Economic Institutions of CaPitalism 8586 (1985); see also Oliver Hart, An Economist's Perspective on the Theory of the Firm, 89 COLUM. L. REV. 1757, 1770 (1989) (noting that "highly complementary assets should be owned in common, which may provide a minimum size for the firm."). Of course, the one-time costs of vertical integration can be quite significant.

89. Indeed, to the extent that the licensing agreement with the first-generation inventor would have involved a "reach-through" royalty - that is, a royalty based upon sales of the product-vertical integration could reduce not only R\&D cost but also marginal cost and thus allow the integrated company to charge a lower profit-maximizing price.

90. See supra note 85 .

91. See John F. Duffy, A Prospect Patent's Power to Coordinate Further Innovation (2001) (unpublished manuscript, on file with author).

92. Id. at 17-20. 
the pioneer patents covered reproducing an image via a photo-electrostatic method. ${ }^{93}$ By way of contrast, consider what might have happened if the broad patent on the Cohen-Boyer method for insertion of a specific gene into a host cell ${ }^{94}$ had been owned and developed solely by a single, vertically integrated firm. It is unlikely that this single firm would have seen the myriad improvements on, or applications of, this technique. Fortunately for the progress of recombinant DNA technology, the patent on the Cohen-Boyer technique was owned by an academic institution (Stanford University) and licensed widely at a reasonable price. ${ }^{95}$

To be sure, if patent rights on upstream research were extremely narrow-so that, for example, a patent on a given product or process covered only the particular use of the product or process identified by the patentee ${ }^{96}$ - vertical integration might not pose an undue threat to competition. Because multiple vertically integrated companies would presumably exist in this situation, integration would have the effect of reducing transaction costs without hindering competition. On the other hand, such narrow patents on upstream research might not provide sufficient incentives for innovation-whether initial invention or subsequent developmentespecially in cases where the upstream research was expensive and not subsidized by public funding. ${ }^{97}$

An approach that would allow slightly broader-albeit still narrowpatents, while permitting the pursuit of multiple research paths, might rely on tightly linked vertical alliances that stop short of complete merger. Under this regime, an inventor with an upstream patent could develop the patent by forming collaborative alliances with multiple downstream companies. Given that the alliances would be tightly linked (e.g., the participants might commit to some level of cross-ownership or they might, from the very outset, share innovation costs and rewards), transaction costs might, over the long term, be lower than in situations of bilateral monopoly or even arm's-length ex ante licensing (albeit perhaps not as low as in the case of complete vertical integration). Indeed, the apparent trend to-

93. Id. at 17.

94. See Stanley N. Cohen et al., Construction of Biologically Functional Bacterial Plasmids in Vitro, 70 ProC. NAT'L ACAD. SCI. USA 3240 (1973).

95. See Rebecca Eisenberg, Public Research and Private Development: Patents and Technology Transfer in Government-Sponsored Research, 82 VA. L. REV. 1663, 1710 (1996).

96. For discussion of how the doctrinal tools of patent law could accomplish this result, see discussion in Part III.C infra.

97. See supra note 24 . 
wards tightly linked alliances ${ }^{98}$ suggests that they may represent a mechanism for reducing transaction costs.

One caveat that attends this proposal for tightly linked alliances is that in situations involving cross-ownership, a downstream developer may place pressure on the upstream inventor in which it holds an equity share not to pursue research alliances that could interfere with the downstream developer's existing products. However, to the extent that we allow anything other than the narrowest patents, the goals of creative development and low transaction costs are somewhat in tension with each another. It will be difficult to achieve an optimum result with respect to both goals. Tightly linked vertical alliances hold out the possibility of a reasonable compromise between the two goals.

It bears emphasis that my suggestion for narrow rights on upstream research applies only to cumulative innovation in the biopharmaceutical industry. ${ }^{99}$ Indeed, I would argue that because the language of the patent statute is broad, and because patents play such different roles in different industries, courts can, and should, develop a federal common law of patents that is tailored to the economic realities of different industries. Notably, to the extent that courts have already developed such common law, it has not been as subject to interest group influence in favor of stronger protection as legislative development of sui generis regimes for different industries. $^{100}$

One final argument against broad upstream patents as a means of coordinating multiple research paths efficiently merits attention. As a doctrinal matter, the idealized Kitchean scenario where downstream developers have to deal with one, and only one, holder of a broad upstream patent is unlikely to arise. This is because patent law does in fact allow blocking patents. For example, even if a patent applicant were granted a broad patent claim on a gene fragment-one that covered not only the fragment but also the parent gene, as well as potential therapeutic applications-an improver might still be able to obtain a patent on the gene itself. As a conse-

98. See supra notes 15-18 and accompanying text.

99. However, a regime of narrow rights on upstream research may well be suitable for other industries that rely on cumulative innovation. $C f$. Cohen \& Lemley, supra note 31 (advocating narrow scope for software patents on the grounds that software innovation is cumulative).

100. See, e.g., Julie Cohen, Lochner in Cyberspace: The New Economic Orthodoxy of "Rights Management," 97 MICH. L. REV. 462, 534-36 (1998) (discussing copyright legislation that gives increased intellectual property rights in the computer software and digital media industries). By contrast, judicial decisions in the biotechnology area have afforded upstream patents a relatively narrow scope. See infra notes 100-117 and accompanying text. 
quence, a third party that wanted to do research on the gene would have to seek licenses from two different parties-the improver and the initial patentee. $^{101}$

Ultimately, then, the importance of multiple research paths to biomedical research, and the transaction cost difficulties associated with pursuing these multiple paths through tailored licensing of a broad patent, counsel in favor of relatively narrow upstream rights. If the rights in question are extremely narrow, even vertical integration may be acceptable as a means of reducing transaction costs. If upstream rights need to be less narrow, however, vertical alliances that fall short of complete integration might be a useful mechanism for mediating the tension between the goals of creative development and low transaction costs.

\section{How Patent Law Can Foster Competition}

For the reasons outlined above, we should be wary of situations where a single firm has broad power over upstream research with uncertain and potentially numerous applications. In the biopharmaceutical industry, the acquisition of such broad power is likely to be a function of patent availability and scope. Thus patent law has an obvious role to play in averting attempts to acquire such power ex ante (as contrasted with antitrust law, which would have to come in to restrict the power conferred by a patent, or multiple patents, ex post). The acquisition of broad power can be thwarted by ensuring that the most upstream research remains outside the bounds of patentability. Even more importantly, various biotechnologyspecific doctrines of patent law that have already been developed by the Federal Circuit and the U.S. Patent and Trademark Office ("PTO") can ensure that rights in research that is patentable but nonetheless quite upstream are defined relatively narrowly. In this regard, it bears emphasis that even narrow patent rights on upstream research may create sufficient incentives for producing this research, either because the research is relatively inexpensive or because it is, at least in part, publicly funded. For example, upstream research on gene fragments or SNPs of unknown function is relatively inexpensive to generate. ${ }^{102}$

101. In fairness to prospect theorists, it should be noted that rights dispersion can be a problem (though not as much of a problem) whether or not broad patents are allowed. I address this issue in Parts III.C and IV.A.

102. See Hugh Reinhoff, President, DNA Sciences, Presentation at Univ. of Calif., Berkeley, Advanced Patent Law Institute (Nov. 10, 2000) (estimating that the cost of finding a gene fragment or SNP of unknown function is about 1 percent of the cost of determining its function). 
In various ways, the doctrinal tools of patent law facilitate drawing the line between patentable and unpatentable invention. ${ }^{103}$ In theory, any of the various patentability requirements-patentable subject matter, ${ }^{104}$ utility, ${ }^{105}$ nonobviousness, ${ }^{106}$ or enablement and written description ${ }^{107}$-could be used. In practice, however, only the utility requirement serves as a particularly good proxy for differentiating upstream from downstream research. ${ }^{108}$ Thus, for example, if the utility requirement were interpreted as strictly as it was in the 1966 Supreme Court case Brenner v. Manson, ${ }^{109}$ inventions that were useful for further research but had not been associated with a specific therapeutic use would probably not be considered patentable. The Brenner case goes too far in its exclusion of virtually all invention with a research use from patentability. After all, only the ultimate end product in the cumulative biopharmaceutical innovation process is likely to have a specific therapeutic use. On the other hand, a stance such as the one the PTO hinted at adopting in the late 1990s - that utility can be shown through a credible assertion of any research use ${ }^{110}$ - goes too far in the opposite direction.

103. In addition to (and in conjunction with) legal doctrine, quasi-private behavior in the form of scientific research norms is an important institution that can be deployed for purposes of limiting the reach of the patent law. See generally Arti K. Rai, Regulating Scientific Research: Intellectual Property Rights and the Norms of Science, 94 Nw. U. L. REV. 77 (1999). In this Article, however, I focus on legal doctrine.

104. 35 U.S.C. \$ 101 (1994).

105. Id. $\S \S 101,112$.

106. Id. \$103.

107. Id. $\$ 112$.

108. Of course, to the extent that the Federal Circuit has interpreted the patentable subject matter requirement as nothing more than a utility requirement, see, e.g., State Street Bank \& Trust Co. v. Signature Fin. Group Inc., 149 F.3d 1368, 1375 (Fed. Cir. 1998) (noting that "[t]he question of whether a claim encompasses statutory subject matter should not focus on which of the four categories of subject matter a claim is directed to-process, machine, manufacture, or composition of matter-but rather on the essential characteristics of the subject matter, in particular, its practical utility." (footnote omitted)), the patentable subject matter requirement could presumably also serve a gatekeeping function. A more robust nonobviousness requirement might also play some role in excluding claims to the most upstream research, such as claims to DNA sequences of unknown function that can be generated without much effort. Currently, under the Federal Circuit's interpretation of nonobviousness, because methods cannot be appropriate prior art for DNA claims, In re Deuel, 51 F.3d 1552, 1557-58 (Fed. Cir. 1995), DNA sequences that are easy to generate can nonetheless be patentable. However, strengthening the nonobviousness requirement might be overinclusive, as a more robust requirement would apply not only to upstream research but also to downstream research.

109. 383 U.S. 519 (1966) (holding that process for producing steroid that was being tested for possible tumor-inhibiting effects in mice did not satisfy the utility requirement).

110. See Rai, supra note 103, at 106-07 (discussing 1997 PTO announcement). 
Fortunately, the PTO's most recent utility guidelines, issued in interim form at the end of 1999 and in final form in January 2001, reveal a more balanced position. The new guidelines appear to exclude most upstream research from patentability, unless it has a "specific, substantial, and credible utility." 111 Under this standard, the thousands of patent applications that have been filed on DNA sequences (and other genetic or protein information) of unknown function are likely to be rejected. ${ }^{112}$ If gene fragments of unknown function are not patentable, they cannot be asserted to block research on the full genes to which they correspond. Similarly, SNPs of unknown function cannot be used to block research on precision drugs.

Although excluding certain inventions from patent protection altogether can assist in the preservation of competition, this approach is likely to play a relatively limited role. As noted, a utility requirement that is too robust would exclude most biopharmaceutical inventions from patentability. Thus the central question in most cases should be not whether a patent of some sort should be granted but, rather, precisely how the scope of the patent should be defined. Within patent law, a variety of doctrinal mechanisms can limit the scope of a claim. The most doctrinally grounded limitations on claim scope are those created by the disclosure-related doctrines of enablement and written description. ${ }^{113}$ Indeed, in recent years, the Federal Circuit has given both of these doctrines-particularly written description-a rigorous interpretation in the context of biotechnology. In Regents of the University of California v. Eli Lilly \& Co., the Federal Circuit applied the written description requirement so as to restrict the patentee (the University of California) to the rat insulin-encoding DNA se-

111. See Utility Examination Guidelines, 66 Fed. Reg. 1092, 1098 (Jan. 5, 2001). Notably, at least at the PTO level, these changes appear to have emerged in part because of pressure from the research science community, a significant portion of which continues to resist broad patenting of the most upstream research. Admittedly, however, these changes in the utility standard have not gone as far as the research science community might have liked. See NIH Opposes Plans for Patenting "Similar" Gene Sequences, 405 NATURE 3 (2000) (discussing opposition by NIH and the Association of American Medical Colleges to PTO decision allowing assertions of utility based on homology to known sequences).

112. See PTO, Revised Interim Utility Guidelines Training Material $50-53$ (2000), http://www.uspto.gov/web/offices/pac/utility/utilityguide.pdf.

113. To be sure, for purposes of limiting patent scope, enablement has a longer doctrinal pedigree than written description. Nonetheless, the Federal Circuit has aggressively revived the role of the written description requirement in recent years. See Regents of the Univ. of Cal. v. Eli Lilly \& Co., 119 F.3d 1559 (Fed. Cir. 1997); cf. Amgen, Inc. v. Chugai Pharm. Co., 927 F.2d 1200 (Fed. Cir. 1991) (using enablement to restrict the scope of DNA claim). 
quences it had actually isolated. The court refused to allow the patentee to extend its patent to analogous sequences in other species. ${ }^{114}$ According to the Federal Circuit, the University of California could not claim human insulin-encoding DNA simply by relying upon the disclosure of a method of using rat DNA to isolate the human DNA. ${ }^{115} \mathrm{~A}$ claim to the human DNA required actual isolation of that DNA. Although Eli Lilly goes too far in narrowing claim scope in the context of DNA sequences, ${ }^{116}$ the decision does have the salutary effect of sounding a warning signal to biotechnology patentees who might be tempted to claim their inventions too broadly. ${ }^{117}$ In response to Eli Lilly, the PTO has promulgated written description guidelines cautioning against sweeping claims on research, particularly in the field of biotechnology. ${ }^{118}$ To the extent patents on gene fragments are issued (and they will presumably be issued only if the patentee shows a "specific, tangible, and credible" utility), these patents will be quite narrow in scope and are not likely to have blocking power with respect to later-isolated full genes. ${ }^{119}$ While the PTO guidelines reflect the Federal Circuit's position, they also respond quite specifically to concerns lodged both by the National Institutes of Health and the academic research community about the problems for subsequent researchers created by broad patents on upstream research. ${ }^{120}$

In most cases, limitations on patent scope created through strict interpretations of the patent law's disclosure doctrines can avoid the problem of excessive concentration of upstream research power in one firm. ${ }^{121}$ But

114. Regents, 119 F.3d at 1568-69.

115. Id. at 1567.

116. See Janice M. Mueller, The Evolving Application of the Written Description Requirement to Biotechnological Inventions, 13 BERKELEY TECH. L.J. 615 (1998) (providing a cogent criticism of the Eli Lilly decision).

117. The PTO's written description guidelines interpreting the Eli Lilly decision soften its implications to some extent-the guidelines make it clear that, in the context of a DNA sequence claim, the written description requirement can be met through mechanisms other than actual isolation of the sequence. See Guidelines for Examination of Patent Applications Under the 35 U.S.C. § 112, II 1, "Written Description" Requirement, 66 Fed. Reg. 1099 (Jan. 5, 2001).

118. Id.

119. See PTO, Synopsis of Application of Written Description Guidelines 30-32, http://www.uspto.gov/web/menu/written.pdf (last visited Apr. 21, 2001).

120. See Jack Spiegel, National Institutes of Health, Comment 64 on the Interim Utility Guidelines 10-11 (Mar. 22, 2000), http://www.uspto.gov/web/offices/com/sol/ comments/utilitywd/nihjs.pdf.

121. Situations in which such concentrations might nonetheless occur, such as mergers or accumulation of a large number of narrow patents by one firm, are discussed in Part IV.B infra. 
narrowly drafted claims can only mitigate, not prevent, the problem of excessive rights proliferation. Consider, for example, the case of a downstream firm that wants to develop a drug for a disease influenced by multiple genes. Even if the patents on each of these genes are relatively narrow (claiming, for example, only the gene itself), they might be owned by different entities. Thus the downstream developer might be placed in the difficult position of seeking improvement licenses from multiple owners. Similarly, a company that wants to develop a DNA microarray of "chip" SNPs that can determine the likelihood of an adverse drug reaction ${ }^{22}$ might have to seek licenses from numerous different SNP patent owners. ${ }^{123}$

In these and similar cases, even narrow patent claims can create impediments to competition in research and development, particularly if there is no possibility of "inventing around" even the narrow claims. In the worst case scenario, if firms interested in developing certain downstream products fail to aggregate rights to upstream research (or at least do so in a manner short of horizontal merger of the upstream owners, which recreates the concentration problem all over again), R\&D competition may be reduced to zero. To avert this problem, we might be tempted to consider alternative limitations on patent scope that are less doctrinally orthodox. One obvious, albeit controversial, scope-limiting doctrine is compulsory licensing. Compulsory licensing may or may not require royalty payments. ${ }^{124}$ Rebecca Eisenberg has suggested that in cases of improvement research, firms ought to be allowed to use patented upstream research free of charge. ${ }^{125}$ If the improvement turned out to be commercially valuable, however, the improver would have to pay a reasonable royalty to the upstream researcher. Similarly, John Barton has suggested that improvers that make significant contributions be given a "dependency license," which requires only the payment of reasonable royalties. ${ }^{126}$

122. For lucid discussions of the use of SNPs in predicting adverse drug reactions, see, for example, Allen D. Roses, Pharmacogenetics and the Practice of Medicine, 405 NATURE 857 (2000); John N. Weinstein, Pharmacogenomics--Teaching Old Drugs New Tricks, 343 NEW ENGLAND. J. MED. 1408 (2000).

123. In this case, the SNPs would be patentable because their function had been identified.

124. The latter case of royalty-free licensing would resemble the copyright fair use doctrine.

125. Rebecca S. Eisenberg, Patents and the Progress of Science: Exclusive Rights and Experimental Use, 56 U. CHI. L. REV. 1017, 1076-77 (1989).

126. Barton, supra note 30, at 458; $c f$. Maureen A. O'Rourke, Toward a Doctrine of Fair Use in Patent Law, 100 CoLUM. L. REV. 1177 (2000) (suggesting five-factor test under which royalty-free or royalty-bearing fair use might be applicable to users of pat- 
Although some form of compulsory licensing for upstream research could be advisable in other industries, the use of compulsory licensing in the biopharmaceutical industry may not be wise. The biopharmaceutical industry is heavily dependent on patent law, and a compulsory licensing requirement may be too radical a departure from the existing regime, under which patent owners almost always have the ability to choose whether they want to license. ${ }^{127}$ The patent owner's freedom to choose whether to license is particularly strong where patents are narrow: as discussed further below, ${ }^{128}$ even under a relatively expansive interpretation of antitrust principles, the only situation where a patent owner can plausibly be forced into compulsory licensing is if it accumulates enough narrow patents to confer monopoly power in a relevant market. ${ }^{129}$ Although such a situation may arise on occasion, it is best dealt with under the antitrust law. I therefore address questions of monopoly achieved through patent accumulation in Part IV. ${ }^{130}$

Within patent law itself, compulsory licensing should be used only infrequently. Commercial improvers should not, as a routine matter, be putting courts in the institutionally awkward position of setting royalties for compulsory licenses. A conservative approach to compulsory licensing would encourage the improver to attempt in the first instance to secure a license through an ordinary market transaction. Compulsory licensing would only be allowed if the improver could prove that a market transaction was thwarted by highly strategic behavior on the part of the patentee (for example, if the improver could show that a given upstream patent holder was "holding out" for a large stake of the surplus after the improver had already concluded licenses with other upstream patent holders). Under this proposed regime, compulsory licensing for pure research uses would be presumptively available (and might even be royalty-free). If a research

ented inventions). O'Rourke's proposed test would tend to allow a fair use defense where (1) the infringement represented a significant advance over the patented work, (2) the use was noncommercial or only indirectly commercial (i.e., a step towards production of a noninfringing work), (3) the market failure that thwarted the conclusion of a license was strong, (4) the effect of finding fair use would not unduly detract from the patentee's incentives or overall social welfare, and (5) the patented work itself was not a pioneering invention. Id. at 1205-08.

127. See In re Indep. Serv. Orgs. Antitrust Litig., 203 F.3d 1322, 1326 (Fed. Cir. 2000) (emphasizing section 271(d) of the Patent Act, which states that patent owners shall not be guilty of "[patent] misuse or illegal extension of the patent right by reason of ... having ... refused to license or use any rights to the patent").

128. See infra Part IV.

129. Id.

130. Id. 
use did yield a commercial product, however, the burden of securing a license to market the product would shift back to the improver. Compulsory licensing would be imposed only if the improver could show significant strategic behavior on the part of the patentee.

In sum, appropriate development of upstream research in the biomedical arena requires the pursuit of multiple research paths. If, through the mechanism of a broad patent, power over upstream research is concentrated in one firm, the firm will not be able to pursue plural paths unless it licenses its patent to multiple developers. Transaction costs are likely to impede such coordinated licensing. Restricting the availability and scope of upstream patents would be more conducive to the pursuit of multiple research paths. Indeed, if such patents were extremely narrow-for example, limited to the particular utility discovered by the patentee-even complete vertical integration would not pose a threat to the pursuit of multiple research paths. Because such radically narrow patents might unduly undermine incentives, however, a more cautious approach is probably preferable. This cautious approach would rely on a combination of narrow patents and vertical alliances to mediate the tension between creative development and transaction costs. In addition, a small background threat of compulsory licensing could curb tendencies on the part of upstream patentees to exercise a "holdup" right.

\section{OVERCOMING LINGERING IMPEDIMENTS TO COMPETITION: THE ROLE OF ANTITRUST LAW}

If the disclosure requirements of patent law are used to limit the scope of patent claims, and the potential for strategic behavior on the part of the upstream patentee is mitigated through a small background threat of compulsory licensing, what (if any) role should innovation markets analysis play in promoting competition? In this Part, I suggest a variety of situations in which innovation markets analysis could be used to evaluate market transactions, particularly transactions between horizontal competitors, for their impact on competition. ${ }^{131}$ In many cases involving cooperation among horizontal competitors, such analysis might actually provide an added impetus for approving such transactions. Indeed, given the difficulty of defining innovation markets, the role of the theory in limiting market actors should be relatively narrow. In a small number of cases, however, where an upstream patent owner is poised to gain control over

131. I focus on horizontal competitors because they pose the main threat to competition. So long as a sufficient number of horizontal competitors exist, vertical integration cannot stymie competition in either R\&D or product markets. 
what appears to be an important platform technology, innovation markets analysis will play an important restrictive role.

\section{A. Encouraging Cooperative Interactions Between Horizontal Competitors}

Innovation markets analysis might encourage certain cooperative interactions between horizontal competitors that promote R\&D. For example, joint ventures in which horizontal competitors collaborate on R\&D for purposes of a specific project can spread the risks associated with the project without effecting a permanent consolidation of patent rights. ${ }^{132}$ In addition, innovation market theorists have recognized that certain types of joint ventures short of a merger (and perhaps even certain mergers) might enhance overall $R \& D$ by creating efficiencies in the $R \& D$ process that overcome any anticompetitive effects. ${ }^{133}$

For purposes of the biopharmaceutical industry in the near future, the most important type of horizontal cooperation between competitors may be cooperation that addresses the rights dispersion problem discussed above. In certain contexts, cross-licensing or patent pool arrangements may be very useful for addressing rights dispersion in a procompetitive manner. In other words, properly designed cross-licensing and patent pooling arrangements can promote innovation markets. As the 1995 Antitrust Guidelines for the Licensing of Intellectual Property note, such arrangements "may provide procompetitive benefits by integrating complementary technologies, reducing transaction costs, clearing blocking positions, and avoiding costly infringement litigation."134

Patent pools typically function by extending membership to those firms in an industry that agree to assign or license their individual patents

132. The analysis in the text focuses on innovation markets. However, to the extent that the joint venturers continue to compete on price and output, the joint venture may have direct welfare-enhancing effects in end-product markets. Congress has recognized these welfare-enhancing effects by passing legislation that offers protection from antitrust scrutiny for registered research joint ventures as well as registered production joint ventures. These joint ventures are protected under the National Cooperative Research Act of 1984, 15 U.S.C. $\S \S 4301-4305$ (1994), as amended by the National Cooperative Research and Production Act of 1993, 15 U.S.C. $\$ \S 4301-05$ (1994). For an analysis that was important in getting the latter legislation passed, see Thomas Jorde \& David Teece, Innovation, Cooperation, and Antitrust: Striking the Right Balance, 4 HIGH TECH. L.J. 1 (1989).

133. See supra note 53 and accompanying text.

134. Licensing Guidelines, supra note $48, \S 5.5$; see also Barton, supra note 30 , at 462-63 (noting that antitrust analysis is easy in the situation where "firms cross-license in order to enable each other to compete"). 
to the pool. ${ }^{135}$ Depending on the sophistication of the pool, members may give one another royalty-free licensing of all the patents or they may pay (or receive) a set fee per patent claim. As for those who cannot contribute patented technology, they may be able to secure a license to the patents in the pool by paying a licensing fee. During the Clinton Administration, the Justice Department approved several different pools that illustrate the central features of a procompetitive pooling scheme. One of these pools comprises various companies that own patents essential for compliance with the MPEG-2 compression technology standard. ${ }^{136}$ Another comprises electronic companies that own patents essential to the manufacture of DVDs and players made in compliance with DVD-ROM and DVD-Video formats. ${ }^{137}$ Because each of these pools is limited to patents that an independent expert has determined are essential ${ }^{138}$-in other words, complementary patents that would not otherwise compete against one another ${ }^{139}$-neither pool forecloses competition. In addition, contributing members of each patent pool agree to license the patent portfolio on a nondiscriminatory basis to all firms that request a portfolio license. ${ }^{140}$ Owners of portfolio patents are also free to license their own patents independent of the portfolio. ${ }^{141}$

In prior writing, I have argued that comprehensive patent pools often emerge only with difficulty, ${ }^{142}$ and are probably less likely to arise in the

135. See, e.g., Robert P. Merges, Contracting into Liability Rules: Intellectual Property Rights and Collective Rights Organizations, 84 CALIF. L. REV. 1293, 1340-42 (1996).

136. See Business Review Letter, MPEG-2 Patent Pool, from Joel I. Klein, Assistant Attorney General, to Garrard R. Beeney, Esq., Sullivan and Cromwell (June 26, 1997), reprinted in Technology Licensing and Litigation 1998: Protecting Your Clients' Rights, 514 PLI/PAT 729 (1998).

137. See Phillips, Sony, and Pioneer Business Review Letter, from Joel I. Klein, Assistant Attorney General, to Garrard R. Beeney, Esq., Sullivan and Cromwell (Dec. 16, 1998), reprinted in Handling Intellectual Property Issues in Business Transaction, 55 PLI/PAT 201 (1999).

138. See Klein, supra note 136; Klein, supra note 137; see also UNITED STATES PATent and TRademark Office, PATENT PoOls: A SOlution to the PROBlem of ACCESS IN BIOTECHNOLOGY PATENTS? 13 [hereinafter PATENT POOLS] (summarizing characteristics of recent, "successful" patent pools).

139. To be sure, the question of whether patents are "truly" complementary can be a difficult one. However, it lies at the heart of determining whether a particular patent pool (or merger of patents more generally) is procompetitive or anticompetitive with respect to innovation.

140. See Klein, supra note 136; Klein, supra note 137.

141. Klein, supra note 136; Klein, supra note 137.

142. Rai, supra note 103 , at $130-32$. 
biopharmaceutical industry than in other areas. ${ }^{143}$ Patent pools are most likely to arise when horizontal competitors who share similar values and are engaged in repeat-play transactions each hold roughly similar portfolios of blocking patents. Where the relevant parties are quite heterogeneous, and each party has a different patent position and attitude toward patents, pools are less likely to arise. ${ }^{144}$ Historically, the biopharmaceutical industry, which encompasses academic institutions, upstream biotechnology companies, and downstream pharmaceutical companies, has been characterized by precisely this type of heterogeneity. ${ }^{145}$ On the other hand, as we see increasing vertical integration, whether in the form of actual mergers or in the form of tightly linked alliances, ${ }^{146}$ heterogeneity in the industry is likely to decrease. Moreover, if patent scope in the biotechnology industry is narrow, as the current positions taken by the PTO and the Federal Circuit suggest it will be, any single patent will be less crucial, and norms of collective exchange may emerge more readily. ${ }^{147}$

In the biotechnology context, a patent pool might be formed in cases where multiple patents are absolutely necessary to conduct basic research on a gene or a particular disease. Consider the product patent held by $\mathrm{Hu}-$ man Genome Sciences ("HGS") on the gene for the CCR5 protein. At the time HGS filed for and acquired the patent, the firm knew very little about the ultimate role of the protein. The HGS patent application merely speculated about the protein's possible role in diseases ranging from cancer to allergies to arthritis. Four different research teams subsequently found that the protein plays a role in HIV infection by promoting virus entry into host cells. All four groups of researchers are now seeking patents covering their research into the role of CCR5 in HIV infection. ${ }^{48}$ If these patents are granted, we will have a classic blocking patents situation. Absent a license, neither HGS nor any of the improvers-nor any other company for that matter - will be able to conduct further research on AIDS that uses the CCR5 protein. By contrast, if HGS and the improvers pooled their patents in a manner similar to the pooling found in the MPEG-2 and DVD pools,

143. Id. at 133-35; see also Heller \& Eisenberg, supra note 87, at 700-01.

144. Heller \& Eisenberg, supra note 87, at 700-01.

145. Id.

146. See supra Part III.B.

147. Some commentators have also perceived a trend towards greater certainty in biotechnology patent law and have argued that this increase in certainty will facilitate the formation of patent pools. See Lawrence M. Sung \& Don J. Pelto, Greater Predictability May Result in Patent Pools: As the Federal Circuit Refines Scope of Biotech Claims, Use of Collective Rights Becomes Likely, NAT'L L.J., June 22, 1998, at C2.

148. Inside the Industry Gene Patent: CCR5 Dispute May Hamper AIDS Research, AMERICAN POLITICAL NETWORK-AMERICAN HEALTH LINE, Mar. 17, 2000, at 6. 
multiple parties (not simply HGS and the improvers) could conduct AIDS research using the CCR5 protein.

To be sure, the MPEG-2 and DVD patent pools represent something of a high-water mark of procompetitiveness in a patent pool. Since patent pools are often more problematic for competition than these examples suggest, it is important to consider the shortcomings of patent pools. More generally, it is important to consider situations where the innovation market thesis might be used to restrict market transactions.

First, the lack of open access that marks some patent pools is problematic to the extent that the excluded firms cannot compete effectively in the relevant $R \& D$ market absent access to the pool. ${ }^{149}$ In addition to access restriction, another feature of patent pools that might signal anticompetitive effects would be a grantback requirement, to the effect that members grant licenses to each other for any future technology they developed using the pool license. ${ }^{150}$ If pool members were forced to share their successful $R \& D$, incentives to free-ride might diminish innovation. Again, this problem would be particularly acute if the pooling arrangement included a significant fraction of the R\&D in an innovation market. ${ }^{151}$ Finally, patent pools may be problematic if they are used to shield invalid patents or they include patents that are not truly complementary (i.e., patents that could compete against each other). ${ }^{152}$

In the next section, I discuss how innovation markets analysis could address anti-competitive behavior within patent pools and also outside of such pools.

\section{B. Restrictive Implications of Innovation Markets Analysis}

If patent rights are kept narrow and are aggregated through procompetitive patent pools rather than horizontal consolidation, innovation markets analysis will, for the most part, encourage market transactions rather than restrict them. However, there will be situations in which innovation markets analysis will have restrictive implications. For example, to the extent that patent pools include patents that could be the basis for competition, include invalid patents, or impose restrictive terms on access, such pools do not promote innovation and should be the basis for antitrust scrutiny. The FTC's complaint that the patent pool created by VISX and

149. Licensing Guidelines, supra note 48 , at 22.

150. In general, a grantback is an arrangement under which a licensee agrees to extend to the licensor of the patent a right a use the licensee's improvements to the licensed technology.

151. Licensing Guidelines, supra note 48, at 23.

152. PATENT POOLS, supra note 138 , at 10. 
Summit Technology, the only two manufacturers of a particular type of laser, included patents that could have been the basis for competition between the two manufacturers, is an example of such scrutiny. ${ }^{153}$ In addition, to the extent that grantback clauses are allowed within patent pools, they should probably be limited to situations where the invention is essential to the operation of the pool. ${ }^{154}$

Even outside the context of a patent pool, grantback clauses could be a competitive hindrance. As the DOJ/FTC guidelines note, grantback clauses can adversely affect competition if they "substantially reduce the licensee's incentive to engage in research and development and thereby limit rivalry in innovation markets." ${ }^{\text {555 }}$ The guidelines counsel that grantback provisions should be scrutinized to determine whether (1) the licensor has significant market power in the relevant innovation market, (2) the grantback is likely to reduce significantly the licensee's incentive to invest in improving the licensed technology, and (3) the grantback provision has offsetting procompetitive effects. Thus, as a general matter, grantback clauses should be scrutinized carefully for anticompetitive effects.

Perhaps most obviously, innovation markets analysis may have a restrictive impact in situations where a single entity accumulates patents sufficient to monopolize a given area of $R \& D$. As discussed in the next section, this is most likely to occur in the context of mergers. However, it may also occur in other situations (e.g., aggressive patenting by a particular firm such that it owns all of the relevant, if individually narrow, patents in a given field). ${ }^{156}$

153. Id. at 16 .

154. The MPEG-2 and DVD patent pools contained this restriction on grantbacks. Id. at 14 .

155. Id.

156. As a doctrinal matter, it may be more difficult to apply antitrust analysis to a non-merger situation. While section 7 of the Clayton Act can restrain monopoly power in the context of mergers, the non-merger situation would have to be addressed under section 2 of the Sherman Act. Moreover, even courts like the Ninth Circuit that have applied section 2 analysis liberally caution that there exists a presumption in favor of allowing firms that have monopoly power by virtue of ordinary patent accumulation to refuse unilaterally to license competitors. See Image Technical Servs., Inc. v. Eastman Kodak Co., 125 F.3d 1195, 1218 (9th Cir. 1997). In some recent decisions, the Federal Circuit appears to have made this presumption virtually irrefutable. See, e.g., In re Independent Serv. Orgs. Antitrust Litig., 203 F.3d 1322, 1324-28 (2000). One doctrinal approach that has been used by a few courts invokes the "essential facilities doctrine," which states that a monopolist cannot deny to its competitors access to facilities that are necessary to compete in a particular market. E.g., Otter Tail Power Co. V. United States, 410 U.S. 366 (1973). However, the essential facilities doctrine is somewhat suspect, see Abbott B. Lipsky \& J. Gregory Sidak, Essential Facilities, 51 STAN. L. REV. 1187, 1219 (1999) (stat- 


\section{How Do We Define the Innovation Market?}

In each case where innovation markets analysis might be used to impose restraints, the central problem is defining the market. The paradigmatic case of innovation markets analysis is a situation where there exists no goods market. ${ }^{157}$ Where no goods market currently exists, and where R\&D paths are uncertain, it is necessarily difficult to define an innovation market - that is, the potential sources of innovation that might create the goods market. Even proponents of the analysis acknowledge that "[i]n many market circumstances there is so much serendipity in research and development that it is impossible to predict the sources of innovation with reasonable certainty." 158 They note that in these circumstances, an innovation markets approach should not be used. ${ }^{159}$ Because at least some biopharmaceutical R\&D is characterized by a large amount of unpredictability and serendipity, it is therefore important to consider very carefully the circumstances under which the analysis could actually be used in the industry.

Where regulators have applied innovation markets analysis to highly downstream, disease-specific areas, they have been able to use the analysis with some confidence. Thus, for example, in a case involving a merger between Glaxo and Burroughs Wellcome, the FTC defined the relevant innovation market as $\mathrm{R} \& \mathrm{D}$ directed to producing an oral drug to treat migraine attacks. ${ }^{160}$ Glaxo and Burroughs Wellcome were each quite far along in developing a non-injectable form of the drug, and the expectation was that the drugs, when developed, would compete in the market. ${ }^{161}$ The FTC complaint alleged that after the merger, Glaxo could eliminate either its own or Wellcome's R\&D efforts to develop a non-injectable drug. ${ }^{162}$ If such elimination did occur, it would take years for another firm to produce

ing that "essential facilities principles are inherently inconsistent with intellectual property protection"), and the Federal Circuit recently vacated a case in which the district court had invoked the doctrine. Intergraph Corp. v. Intel Corp., 195 F.3d 1346, 1357-58 (Fed. Cir. 2000) (reversing lower court opinion).

157. See supra Part II.B.

158. Gilbert \& Sunshine, Incorporating Dynamic Efficiency Concerns in Merger Analysis, supra note 48, at 596.

159. Id.

160. Balto \& Mongoven, supra note 20 , at 267.

161. Id.

162. Id. 
an alternative. ${ }^{163}$ The case was resolved with the divestiture of Wellcome's $R \& D$ assets in the area. ${ }^{164}$

By contrast, in others cases, the R\&D market on which the FTC has focused has been much more upstream. In those contexts, the application of innovation markets analysis has been less certain. Consider, for example, the FTC's evaluation of the merger between Ciba-Geigy and Sandoz to form Novartis. In that case the FTC alleged the existence of an R\&D market for gene therapy products that would emerge in the future (including in vivo and ex vivo gene therapy). ${ }^{165}$ It argued that the merged firm's combined patent position in gene therapy would allow it to block competitors from engaging in any $R \& D$ with respect to such therapy (and thereby, ultimately, block them from producing competing gene therapy products). ${ }^{166}$ By contrast, as separate firms, Ciba-Geigy and Sandoz had been forced to compete against each other in licensing their gene therapy portfolio. ${ }^{167}$ In its consent order approving the merger, the FTC required the licensing of certain patent rights to another pharmaceutical company (Rhone-Poulenc Rorer) so that Rhone-Poulenc could compete in gene therapy $R \& D$ and could also license rights to the gene therapy patents to other companies. ${ }^{168}$ In addition, the consent order required that one crucial patent-which covered the most advanced area of commercial develop-

163. Id.

164. Id. Similarly, in a case involving a merger between Upjohn and Pharmacia, the FTC alleged that the merger would harm competition in the R\&D market for topoisomerase I inhibitors, which are used to treat colorectal cancer. The merging firms were two of a small number of companies in the advanced stages of developing the inhibitors. The FTC alleged that because these drugs took many years to develop, and only a few other firms were currently producing the drugs, it was unlikely that competition would constrain the merged firm from terminating development of one of the drugs. The case was resolved with divestiture of Pharmacia's topoisomerase I assets to another pharmaceutical company. Id. at 269.

165. In re Ciba-Geigy Ltd., No. 961-0055, 1996 F.T.C. LEXIS 701, *5 (Dec. 5, 1996). The complaint noted that although the first products would not be available until the year 2000 , the product market could grow to $\$ 45$ billion by the year 2010 . Id. at $* 5-6$.

166. The FTC also alleged harm to competition in four R\&D markets for more specific gene therapies. These were the R\&D markets for: (1) herpes simplex virusthymidine ("HSV-tk") gene therapy for the treatment of cancer; (2) HSV-tk gene therapy for the treatment of graft versus host disease; (3) gene therapy for the treatment of hemophilia; and (4) chemoresistance gene therapy. Id. at *5.

167. Although Ciba-Geigy did not itself own gene therapy patents, it was the largest shareholder in Chiron, which held these patents. As of 1996, Ciba-Geigy owned 46.5 percent of Chiron capital stock, funded Chiron research, had the right to appoint members of the Chiron board of directors, and had the right to veto Chiron's actions. Id. at *3-4.

168. Id. at *90-92. 
ment of gene therapy-be made available to all interested parties at low royalties. ${ }^{169}$

It is instructive to compare and contrast the two FTC actions. In the migraines case the $R \& D$ market could be defined with great, perhaps even complete, clarity because the relevant research was so close to yielding a marketable end product. It was highly unlikely that innovation which was a "close substitute" for the Glaxo and Wellcome R\&D on oral migraine medication would emerge during the short period between the FTC evaluation of the transaction and the production of a marketable end product. Indeed, one can make the generalization that once research enters the FDA-mandated clinical testing phase, the R\&D market is going to be relatively easy to define. Not only are we close to the end product but the FDA process itself gives the regulator a great deal of information about the research in question and possible substitutes for that research. ${ }^{170} \mathrm{On}$ the other hand, the competitive benefit associated with the FTC action at that stage may be relatively small-lower prices in the product market for a single medication. ${ }^{171}$

By contrast, in the gene therapy case, because the research was relatively upstream, it was difficult to define the $R \& D$ market with anything close to complete certainty. It was conceivable (although perhaps not likely) that, during the long lag time before gene therapy yielded a marketable product, ${ }^{172}$ other types of innovation that could have been "close substitutes" for gene therapy innovation might have emerged. Indeed, because any closely substitutable research would have been quite upstream, and thus would not have to be disclosed to the FDA, it was certainly possible that close substitutes for the research had already emerged but had been kept secret. However, if these close substitutes did not emerge, and Novartis used its patent power to exclude all competition, the potential

169. Id. at *93-95.

170. One caveat to this generalization bears mention. On occasion, drugs that have already been approved for one indication end up being useful for treating another indication. Physicians can prescribe an approved drug for indications other than the approved indication without the drug's having to go through another approval process. Thus, in the case of the oral migraine medication discussed in the text, it was possible that a drug that had already been approved for another indication would emerge, without the FDA's knowledge, as an oral treatment for migraines.

171. Of course, if the medication is a life-saving drug, this is no small benefit.

172. The FTC complaint itself acknowledged that a marketable product would not be likely to emerge until the early part of the 21 st century, about five years after its evaluation of the merger. See id. at *5-7. 
downside was great. After all, the therapy patents are, at least arguably, as fundamental as the Cohen-Boyer patent on recombinant DNA. ${ }^{173}$

These examples suggest a more general conundrum that regulators applying innovation markets theory to biopharmaceuticals will, on occasion, have to address. Although the utility of the theory is often directly proportional to the certainty with which the market can be defined, there will be cases where this rule of thumb does not hold. In the gene therapy case, for example, the imposition of restrictions based on innovation markets analysis may have been useful even though the innovation market in question was difficult to define. For the most part, if patent scope on upstream invention is kept narrow, regulators will not often have to face the conundrum of having to use innovation markets analysis despite the difficulty of defining the relevant market. But where market transactions threaten to give a single entity control of what appears to be a fundamental platform, the conundrum will have to be faced.

\section{CONCLUSION}

This Article has engaged the question of whether concentration or competition is the more appropriate market structure for the sequential process that is biopharmaceutical innovation. I have argued that, despite the attractions of concentration as a means of appropriating the value of a lengthy and expensive $R \& D$ process, a role for competition needs to be preserved. In the context of the biopharmaceutical industry, broad patents, particularly on upstream research, represent the primary threat to competition. Thus, patent law needs to take the lead in preserving competition, primarily by cabining the scope of patents on upstream inventions. Antitrust law, and especially the theory of innovation markets, should play a secondary role. In this secondary role, innovation markets theory will actually support certain market transactions that aggregate patent rights, in particular procompetitive patent pools. Innovation markets theory will, however, have an important impact in restricting market transactions in those circumstances where the transaction is likely to give a single entity control of what appears to be a fundamental platform technology. In these circumstances, restrictive application of innovation markets theory will be necessary even though there may be uncertainty associated with defining the relevant innovation market.

173. Alternately, it was conceivable that gene therapy of the type generated by the patents at issue would not be a viable therapy at all. In that case, however, the downside of limiting concentration would not have been large (and to some extent still is not, given that gene therapy has yet to yield a marketable product). 
BERKELEY TECHNOLOGY LAW JOURNAL 